\title{
Sludge Biochar Amendment and Alfalfa Revegetation Improve Soil Physicochemical Properties and Increase Diversity of Soil Microbes in Soils from a Rare Earth Element Mining Wasteland
}

\author{
Caigui Luo ${ }^{1,2,3}$ (1), Yangwu Deng ${ }^{1,2,3, *(1)}$, Kazuyuki Inubushi ${ }^{4}$, Jian Liang ${ }^{1,3}$, Sipin Zhu ${ }^{1,3}$, \\ Zhenya Wei ${ }^{1,3}$, Xiaobin Guo ${ }^{2}$ and Xianping Luo ${ }^{1,2,3, *}$ \\ 1 Faculty of Resources and Environmental Engineering, Jiangxi University of Science and Technology, \\ Ganzhou 341000, China; andk24@163.com (C.L.); ljreee@163.com (J.L.); zhusipin926@163.com (S.Z.); \\ m15607077016@163.com (Z.W.) \\ 2 National Engineering Research Center for Ionic Rare Earth, Ganzhou 341000, China; guoxb1964@163.com \\ 3 Jiangxi Key Laboratory of Mining \& Metallurgy Environmental Pollution Control, Ganzhou 341000, China \\ 4 Graduate School of Horticulture, Chiba University, Matsudo, Chiba 2718510, Japan; \\ inubushi@faculty.chiba-u.jp \\ * $\quad$ Correspondence: tosang@foxmail.com (Y.D.); luoxianping9491@163.com (X.L.); Tel: +86-797-831-2754 (Y.D.); \\ $+86-797-832-2706$ (X.L.)
}

Received: 26 March 2018; Accepted: 2 May 2018; Published: 11 May 2018

\begin{abstract}
Long-term unregulated mining of ion-adsorption clays (IAC) in China has resulted in severe ecological destruction and created large areas of wasteland in dire need of rehabilitation. Soil amendment and revegetation are two important means of rehabilitation of IAC mining wasteland. In this study, we used sludge biochar prepared by pyrolysis of municipal sewage sludge as a soil ameliorant, selected alfalfa as a revegetation plant, and conducted pot trials in a climate-controlled chamber. We investigated the effects of alfalfa revegetation, sludge biochar amendment, and their combined amendment on soil physicochemical properties in soil from an IAC mining wasteland as well as the impact of sludge biochar on plant growth. At the same time, we also assessed the impacts of these amendments on the soil microbial community by means of the Illumina Miseq sequences method. Results showed that alfalfa revegetation and sludge biochar both improved soil physicochemical properties and microbial community structure. When alfalfa revegetation and sludge biochar amendment were combined, we detected additive effects on the improvement of soil physicochemical properties as well as increases in the richness and diversity of bacterial and fungal communities. Redundancy analyses suggested that alfalfa revegetation and sludge biochar amendment significantly affected soil microbial community structure. Critical environmental factors consisted of soil available $\mathrm{K}, \mathrm{pH}$, organic matter, carbon-nitrogen ratio, bulk density, and total porosity. Sludge biochar amendment significantly promoted the growth of alfalfa and changed its root morphology. Combining alfalfa the revegetation with sludge biochar amendment may serve to not only achieve the revegetation of IAC mining wasteland, but also address the challenge of municipal sludge disposal by making the waste profitable.
\end{abstract}

Keywords: sludge biochar amendment; alfalfa revegetation; bacterial and fungal communities; ion-adsorption rare earth mining wasteland; soil physicochemical properties

\section{Introduction}

Ion-adsorption clay (IAC) contains rare earth elements (REEs). IAC mines are widely distributed throughout several adjacent provinces of southern China, including Jiangxi, Guangdong, Fujian, 
Guangxi, Hunan, Yunnan, Zhejiang provinces [1]. In the early days of mining, IAC was extracted via tank or heap leaching [2]. These methods cause serious ecological destruction in IAC mining wastelands [3], including loss of vegetation, pollution of water and soil, and geological disasters (e.g., landslides). As a result, the soil in IAC mining wastelands has a loose texture, poor aggregation, low water-holding capacity and fertility, and decreased microbial diversity, all of which makes it hard for plants to colonize these soils. Rehabilitation is urgently needed for IAC mining wastelands and two potential measures are soil amendment and revegetation.

A key step for soil amendment is the selection of an appropriate soil ameliorant. Biochar, which is prepared by slow pyrolysis of biomass under oxygen-limited conditions, has been a focus of research on soil amendments [4-10]. The characteristics of biochar determine how it could improve soil properties. Its porous structure can increase soil porosity [11,12], reduce soil bulk density [13], and provide a habitat for microorganisms [14]. Furthermore, the huge surface area [15] and abundant functional groups (e.g., carboxyls and phenolic hydroxyls) [16] could enhance soil cation exchange capacity (CEC), increase water-holding capacity and decrease fertilizer leaching [17]. The aromatic hydrocarbon structure contributes to the long-term retention of biochar in soil [18]. Biochar can be prepared from a wide range of raw materials, such as agricultural waste [5], animal manure [19], and municipal sludge [20]. It has been proposed that municipal sewage sludge may be an important raw material for biochar preparation because it is rich in mineral nutrients (,$P$ and $\mathrm{K})$ and organic matter [21].

China's yield of municipal sludge has been growing rapidly, with an average increase of more than $10 \%$ each year from 2008 to 2014 and an estimated 34 million tons produced in 2015 [22]. More than 20\% of municipal sludge, which contains pathogens, heavy metals and other pollutants, remains stacked on land on the outskirts of cities [23] where it could threaten human health by entering food or water supplies [24]. Currently, the disposal of municipal sludge is an urgent problem for the government and society. Traditional methods of municipal sludge disposal include agricultural applications, incineration and landfill disposal, all of which have drawbacks, including the fact that these methods require a lot of land resources and result in air pollution, and heavy-metal pollution in soil and water. Pyrolysis is an effective way to dispose of sludge, which is transformed into sludge biochar and used as a soil-amending resource. In addition, sludge biochar can prevent the leaching of heavy metals in raw sewage sludge [25]. Many studies have reported the application of sludge biochar in the remediation of different kinds of sites. Méndez et al. [26] evaluated the effects of sludge biochar derived from sewage sludge on heavy metals solubility and bioavailability in a Mediterranean agricultural soil; the result showed that the risk of leaching of $\mathrm{Cu}, \mathrm{Ni}$ and $\mathrm{Zn}$ were lower in the soil treated with sludge biochar, which also reduced plant availability of $\mathrm{Ni} \mathrm{Zn}, \mathrm{Cd}$ and $\mathrm{Pb}$ when compared with soil treated with raw sewage sludge. Sardar Khan. et al. [18] investigated the impact of sludge biochar upon rice (Oryza sativa L.) yield, metal bioaccumulation and greenhouse gas emissions from acidic paddy soil, and concluded that sludge biochar increased soil $\mathrm{pH}$, total nitrogen, soil organic carbon and available nutrients and decreased bioavailable $\mathrm{As}, \mathrm{Cr}, \mathrm{Co}, \mathrm{Ni}$, and $\mathrm{Pb}$ in soil as well as significantly $(p \leq 0.01)$ increasing shoot biomass, grain yield and the bioaccumulation of phosphorus and sodium. Méndez et al. [27] assessed the influence of sewage sludge and sewage sludge biochar on peat properties as growing media and on lettuce (Lactuca sativa) growth, and they confirmed that sewage sludge transformation into biochar proved to be a sustainable waste management approach in order to promote their future use as growing media components. To our knowledge, little is known about the effect of the use of sludge biochar on the soil properties of IAC mining wastelands.

Revegetation is an important measure used for rehabilitation and a critical step in the use of this measure is the best choice of revegetation plants for a particular site. Alfalfa is an attractive revegetation plant, an important gramineous forage legume, because of its adaptability to climates and soil environments, rapid growth, high yield, and ability to fix nitrogen [28,29]. Alfalfa is widely used in the remediation of heavy metals, oil, and other contaminated soils as well as to ameliorate the effects of degraded soil [30,31]. Alfalfa revegetation has not been tested for soil restoration of IAC mining wastelands. 
Microorganisms in soil play a critical role in cycling materials. The sensitivity of the response of a microbial community, specifically bacterial and fungal communities, reflects a change in soil quality $[32,33]$. For instance, a significant alteration of microbial community in IAC mining wasteland was demonstrated in our previous study [34] and some other reports [35-37]. In this study, we used sludge biochar as a soil ameliorant and alfalfa as the revegetation plant and conducted pot trials in a climate-controlled chamber, and we test the hypothesis that sludge biochar amendment and alfalfa plantation can ameliorate physicochemical properties and increase the microbial diversity of soil from IAC mining wastelands. Our objectives were to determine the effects of alfalfa revegetation and municipal sludge biochar amendment, and both in combination, on the physicochemical properties and microbial communities of soil from IAC mining wastelands. We aimed to not only explore a new way to utilize municipal sludge as a resource, but also to test a new rehabilitation method for IAC mining wastelands.

\section{Materials and Methods}

\subsection{Experimental Soil, Preparation of Sludge Biochar, and Revegetation Plant}

The experimental soil was collected from the top layer $(0-20 \mathrm{~cm}$ ) of the stockpiled soil (an Entisol, specifically an Udarent) after mining in the Chakeng IAC mining wasteland ( $24^{\circ} 56^{\prime} 17^{\prime \prime} \mathrm{N}, 115^{\circ} 03^{\prime} 22^{\prime \prime}$ E), located in Dingnan county, Ganzhou city, Jiangxi province, China. The area has a subtropical humid monsoon climate, with an annual average temperature of $19^{\circ} \mathrm{C}$, an annual rainfall of $1550 \mathrm{~mm}$, and is located in hilly terrain.

The soil was air-dried for 2 day at room temperature, then passed through a $2 \mathrm{~mm}$ mesh sieve and kept at $4{ }^{\circ} \mathrm{C}$ for subsequent trials. The municipal sludge was collected from the dewatering room in the Baitashang wastewater treatment plant $\left(25^{\circ} 89^{\prime} 91^{\prime \prime} \mathrm{N}, 114^{\circ} 94^{\prime} 05^{\prime \prime} \mathrm{E}\right)$ in Ganzhou. The sludge biochar was prepared from air-dried municipal sludge through pyrolysis in a muffle furnace (FO810C, Yamato Scientific, Chongqing, China) in $500{ }^{\circ} \mathrm{C}$ for $2 \mathrm{~h}$ under a continuous flow of nitrogen. The basic physicochemical properties of the experimental soil and sludge biochar are shown in Table 1 . Alfalfa (Medicago sativa) was selected as revegetation plant in this study. Alfalfa seeds (purity: $>98 \%$, germinability: $>85 \%$, from Lantian seed industry Co Ltd., Heze, China) were surface-sterilized with $2 \%$ (volum/volum) hydrogen peroxide for $5 \mathrm{~min}$, then thoroughly rinsed three times with de-ionized water before used in the pot experiment [30].

Table 1. Properties of soil and sludge biochar used in experiments.

\begin{tabular}{ccc}
\hline Samples & Soil & Sludge Biochar \\
\hline Clay $(\%)$ & $7.64 \pm 0.27$ & - \\
Silt $(\%)$ & $15.48 \pm 0.32$ & - \\
Sand $(\%)$ & $76.88 \pm 0.38$ & - \\
$\mathrm{pH}$ & $5.44 \pm 0.02$ & $6.17 \pm 0.03$ \\
Electrical conductivity $(\mu \mathrm{S} / \mathrm{cm})$ & $45.16 \pm 1.03$ & $272.67 \pm 6.06$ \\
Organic carbon $(\mathrm{g} / \mathrm{kg})$ & $0.73 \pm 0.18$ & $97.32 \pm 2.78$ \\
Total nitrogen $(\mathrm{g} / \mathrm{kg})$ & $0.21 \pm 0.03$ & $2.48 \pm 0.02$ \\
C/N ratio & $3.44 \pm 0.37$ & $39.31 \pm 0.72$ \\
Available nitrogen $(\mathrm{mg} / \mathrm{kg})$ & $10.35 \pm 2.58$ & $378.93 \pm 10.19$ \\
Available phosphorus $(\mathrm{mg} / \mathrm{kg})$ & $9.43 \pm 2.31$ & $712.61 \pm 12.24$ \\
Available potassium $(\mathrm{mg} / \mathrm{kg})$ & $10.62 \pm 1.51$ & $172.97 \pm 5.92$ \\
BET surface area $\left(\mathrm{m}^{2} / \mathrm{g}\right)$ & - & $47.03 \pm 0.02$ \\
Pore volume $\left(\mathrm{cm}^{3} / \mathrm{g}\right)$ & - & $0.06 \pm 0.001$ \\
Pore size $(\mathrm{nm})$ & - & $5.16 \pm 0.01$ \\
\hline
\end{tabular}

\subsection{Trial Set-Up and Sampling}

We designed four treatments (Table 2): (1) control soil (CK); (2) soil planted with alfalfa (G); (3) soil amended with $5 \%$ (weight/weight) sludge biochar (SBC); and (4) soil amended with 5\% (w/w) sludge 
biochar and planted with alfalfa (SBCG). Each treatment was replicated three times. Plastic pots $(20.5 \mathrm{~cm}$ diameter, $19.5 \mathrm{~cm}$ tall) filled with soil or a mixture of soil and sludge biochar, $5 \mathrm{~kg}$ per pot, were placed into a climate-controlled chamber for a two-week stabilization. After that, the preconditioned alfalfa seeds, $5 \mathrm{~g}$ per pot, were sown for $\mathrm{G}$ and SBCG treatments. All pots were then incubated further in the climate chamber $\left(25^{\circ} \mathrm{C}\right.$ day, $20^{\circ} \mathrm{C}$ night, $12 / 12 \mathrm{~h}$ ). Alfalfa sprouted in 2 day. During both the stabilization and incubation period, the position of each pot was adjusted randomly every 2 day to minimize location effects.

Table 2. Four treatments were designed in this study.

\begin{tabular}{cccc}
\hline Treatments & Mine Soil $\mathbf{( k g )}$ & Alfalfa Seed $\mathbf{( g )}$ & Sludge Biochar $\mathbf{( k g )}$ \\
\hline CK & 5 & - & - \\
G & 5 & 5 & - \\
SBC & 4.75 & - & 0.25 \\
SBCG & 4.75 & 5 & 0.25 \\
\hline
\end{tabular}

Notes: CK, the control soil; G, soil planted with alfalfa; SBC, soil amended with sludge biochar; SBCG, soil amended with sludge biochar and planted with alfalfa.

When the alfalfa plants reached maturity (about 90 day), a soil sample was taken from each pot and divided into two sub-samples. One sub-sample ( $5 \mathrm{~g}$ fresh soil) was immediately stored in a refrigerator at $-80^{\circ} \mathrm{C}$ until it was used for DNA extraction. The other sub-sample was air-dried, passed successively through $2 \mathrm{~mm}$ and $0.25 \mathrm{~mm}$ mesh sieves, and stored at $4{ }^{\circ} \mathrm{C}$ for physicochemical analysis (about $1000 \mathrm{~g}$ air-dried soil). The plants were harvested from each pot in the G and SBCG treatments and cleaned with tap water and de-ionized water successively for 2-3 min and kept for biomass measurement and root morphology analysis (refer to Section 2.5).

\subsection{Analysis of Soil Physicochemical Properties}

Analysis of soil physicochemical properties was performed according to the standard methods. Specific gravity, bulk density, and total porosity were measured according to [38]. The water-holding capacity of the soil was determined using a previously published method [36]. The determination of the soil's pH level was measured using a pH-meter (STARTER 3100; OHAUS Instruments, Shanghai, China) with a soil-liquid ratio of 1:2.5. Organic matter was determined by potassium dichromate $\left(\mathrm{K}_{2} \mathrm{Cr}_{2} \mathrm{O}_{7}\right)$ oxidation followed by ammonium ferrous sulfate titration. Total nitrogen was measured by high concentration $\mathrm{H}_{2} \mathrm{SO}_{4}$ digestion followed by semi-micro Kjeldahl distillation. Available nitrogen was determined by the alkali solution diffusion method. Determination of available phosphorus was undertaken by the $\mathrm{HCl}-\mathrm{NH}_{4} \mathrm{~F}$ extraction-molybdenum antimony colorimetric method. Available potassium was analyzed by $\mathrm{CH}_{3} \mathrm{COONH}_{4}$ extraction followed by atomic absorption spectrophotometry.

\subsection{Analysis of Soil Microbiota}

\subsubsection{Extraction of Soil DNA}

A $200 \mathrm{mg}$ sub-sample of fresh soil was taken from every sample to extract total community genomic DNA using an E.Z.N.A ${ }^{\mathrm{TM}}$ Mag-Bind Soil DNA Kit (OMEGA Bio-tek, Norcross, GA, USA), according to the manufacturer's instructions.

\subsubsection{Gene Amplification by Polymerase Chain Reaction (PCR) and Illumina Sequencing}

The V4 hyper-variable region of the $16 S$ rRNA gene and internal transcribed spacer region (ITS) were selected as the bacterial and fungal target segments, respectively. The general primers of bacterial 16S rRNA gene were 515F (CCC TAC ACG ACG CTC TTC CGA TCTN (barcode) GTG CCA GCM GCC GCG GTAA) and 805R [39] (GAC TGG AGT TCC TTG GCA CCC GAG AAT TCC AGG ACT ACH VGG GTA TCT AAT CC). The general primers of fungal ITS rRNA were ITS-F (CCC TAC ACG ACG 
CTC TTC CGA TCTN (barcode) CTT GGT CAT TTA GAG GAA GTAA) and ITS-R (GTG ACT GGA GTT CCT TGG CAC CCG AGA ATT CCA GCT GCG TTC TTC ATC GAT GC). All gene amplification was conducted in two rounds with Illumina bridge polymerase chain reaction (PCR)-compatible primers in the second round PCR. The PCR reaction system contained $15 \mu \mathrm{L} 2 \times$ Taq master Mix; $1 \mu \mathrm{L}$ Bar-PCR primer $\mathrm{F}(10 \mu \mathrm{M})$ and primer $\mathrm{F}(10 \mu \mathrm{M})$ for the first and second round, respectively; $1 \mu \mathrm{L}$ Primer R $(10 \mu \mathrm{M}) ; 10 \mathrm{ng}$ and $20 \mathrm{ng}$ genomic DNA for the first and second round, respectively; $\mathrm{H}_{2} \mathrm{O}$ (added to $30 \mu \mathrm{L}$ ). The two rounds of PCR were conducted in a $100^{\mathrm{TM}}$ Thermal Cycler (Bio-Rad Laboratories, Inc., Hercules, CA, USA). The first round of PCR consisted of an initial denaturation step at $94{ }^{\circ} \mathrm{C}$ for $3 \mathrm{~min}$, followed by five cycles of $94{ }^{\circ} \mathrm{C}$ for $30 \mathrm{~s}, 45^{\circ} \mathrm{C}$ for $20 \mathrm{~s}$, and $65^{\circ} \mathrm{C}$ for $20 \mathrm{~s}$, followed by another 20 cycles of $94^{\circ} \mathrm{C}$ for $20 \mathrm{~s}, 55^{\circ} \mathrm{C}$ for $20 \mathrm{~s}$, and $72{ }^{\circ} \mathrm{C}$ for $30 \mathrm{~s}$, and a final extension step at $72{ }^{\circ} \mathrm{C}$ for $5 \mathrm{~min}$. The second round of PCR consisted of a denaturation step at $95^{\circ} \mathrm{C}$ for $30 \mathrm{~s}$, followed by five cycles of $95^{\circ} \mathrm{C}$ for $15 \mathrm{~s}, 55^{\circ} \mathrm{C}$ for $15 \mathrm{~s}$, and $72{ }^{\circ} \mathrm{C}$ for $30 \mathrm{~s}$, and a final extension step at $72{ }^{\circ} \mathrm{C}$ for $5 \mathrm{~min}$. After two rounds of PCR, the size of the PCR products was confirmed by an agarose gel electrophoresis test. The accurate concentrations of purified products were determined using a Qubit 2.0 Fluorometer (Thermo Fisher Scientific, Waltham, MA, USA) and the amplicons from each reaction mixture were then pooled in equi-molar ratios based on their concentration. The treated samples were sent to Sangon BioTech (Shanghai, China) to sequence on the Illumina MiSeq system (Illumina, San Diego, CA, USA), according to the manufacturer's instructions.

\subsubsection{High-Throughput Sequencing Data Processing}

Data from Illumina sequencing was processed and optimized as follows: (1) according to the overlap relationship between paired-end (PE) reads, pair reads were merged into a sequence using the PEAR 0.9.6 software (main parameter: - x 0.1) (Scientific Computing Group, Heidelberg, Germany), and the individual FASTA and QUAL files were generated from the processing of FASTQ files and then analyzed by standard methods; (2) ambiguous sequences were deleted and those with a maximum homo-polymer length of $6 \mathrm{bp}$ were allowed [40]; (3) all identical sequences were merged into one and we recorded the frequency of each sequence to reduce the data calculations; (4) we referred to a customized reference database to align sequences [41]; (5) the completeness of the index and adaptor was checked, and all incomplete sequences were removed; (6) the pre-cluster tool was used to remove noise and the chimera UCHIME algorithm was used to detect chimera sequences; (7) to standardize the sequencing depth of all samples, after quality control, 39,000 bacterial and 30,000 fungal sequences were randomly selected from each sample for the subsequent analyses.

The effective sequences of each sample were submitted to the Ribosomal Database Project (RDP) Classifier (http:/ / rdp.cme.msu.edu/) to identify bacterial and fungal sequences [42]. Mothur [43] was used to calculate microbial richness (ACE and Chao1), diversity (Shannon and Simpson), and coverage.

\subsection{Analysis of Plant Growth and Their Root Morphology}

Plant height was measured with a ruler. The plants from the $G$ and SBCG treatments were oven-dried at $105{ }^{\circ} \mathrm{C}$ to determine their biomass as dry weight (shoot, root, and total). We used a root-scanning system (Wanshen Detection Technology Corp., Hangzhou, China) to evaluate the morphology of alfalfa root, including total root length (TRL), root surface area (RSA), root volume (RV), root average diameter (RAD), root tip number (RTN), and root fork number (RFN) [44].

\subsection{Statistical Analysis}

Soil physicochemical properties, richness (ACE and Chao1), and diversity (Shannon and Simpson) of bacterial and fungal communities (phylum and genus) among four treatments as well as the data of plant growth and their root morphology in G and SBCG treatments were compared by one-way analysis of variance (ANOVA), followed by the Duncan's multiple range test (DMRT), with significance set to $p<0.05$ level [45]. All analyses were conducted in SPSS 17.0 (SPSS Inc., Chicago, IL, USA). All plots were created using Origin 8.5 Pro software (OriginLab Corporation, Northampton MA, USA). 
The principal co-ordinate analyses ( $\mathrm{PCoA}$ ) were conducted with $\mathrm{R}$ software to determine the similarity and differences of microbial community among four treatments at the genus level.

The multiple relationships between bacterial and fungal community structure, and soil physicochemical properties were carried out in Canoco 4.5 (Biomeris, Wageningen, The Netherlands). De-trended corresponded analyses (DCA) [46], with bacterial and fungal composition data were conducted and the lengths of the first DCA ordination axis were 0.109 and 0.325 , which indicated that redundancy analysis (RDA), based on a linear model, should be applied to ordinate the soil bacterial and fungal community structures with physicochemical properties, respectively. The manual selection mode of Monte Carlo permutation test with 499 unrestricted permutations was used to confirm the key environmental factors that significantly influenced the microbial community [47].

\section{Results and Discussion}

\subsection{Response of Soil Physicochemical Properties to Alfalfa Revegetation and Sludge Biochar Amendment}

\subsubsection{Effects on Soil Physical Properties}

The soil physical properties of four treatments are shown in Figure 1. There were significant differences among four treatments. The specific gravity values of $\mathrm{G}(2.55 \pm 0.02), \mathrm{SBC}(2.62 \pm 0.02)$, and SBCG $(2.44 \pm 0.02)$ treatments were all significantly lower than that of the CK treatment $(2.70 \pm 0.03)(p<0.05)$. A similar trend was also observed in the bulk density of four treatments, with those of G, SBC, and SBCG significantly lower than that of CK $(p<0.05)$ by $9.1 \%, 5.6 \%$ and $14.7 \%$, respectively. The lower levels of specific gravity and bulk density in treated soils (G, SBC, and SBCG) suggested that sludge biochar application and alfalfa revegetation both significantly reduced soil compaction and enhanced soil porosity and ventilation, which are attributed to the porous structure of the sludge biochar [18] and the strong root system of alfalfa [48,49]. Total porosity only showed significant differences between CK and SBCG $(p<0.05)$. The soil water-holding capacity values of G, SBC, and SBCG were all significantly higher, by $20.2 \%, 10.2 \%$, and $31.4 \%(p<0.05)$, respectively, than that of CK $(21.59 \pm 1.52 \%)$. A previous study [37] showed that long-term exploitation of rare earth resources had destroyed soil structure (poor porosity and ventilation) in an IAC mining wasteland. The significant increases of total porosity and water-holding capacity in SBCG treatment suggested that the combination of alfalfa revegetation and sludge biochar amendment not only improved soil porosity but also helped maintain water content. Many previous studies have demonstrated that the application of biochar can improve the soil physical properties [50], such as soil aggregation [51], water-retention capacity [52,53], pore-size distribution [54], and bulk density [55]. The application of sludge biochar, by means of providing nutrients (N, P, K) [56], can benefit the growth of alfalfa, which in turn helps ameliorate the soil's physical properties [57]. An additive effect between alfalfa revegetation and sludge biochar amendment was detected first in this study, suggesting the combination of these two variables improved soil physical properties was more intense than either in isolation, which was in accordance with other previous study [58]. 

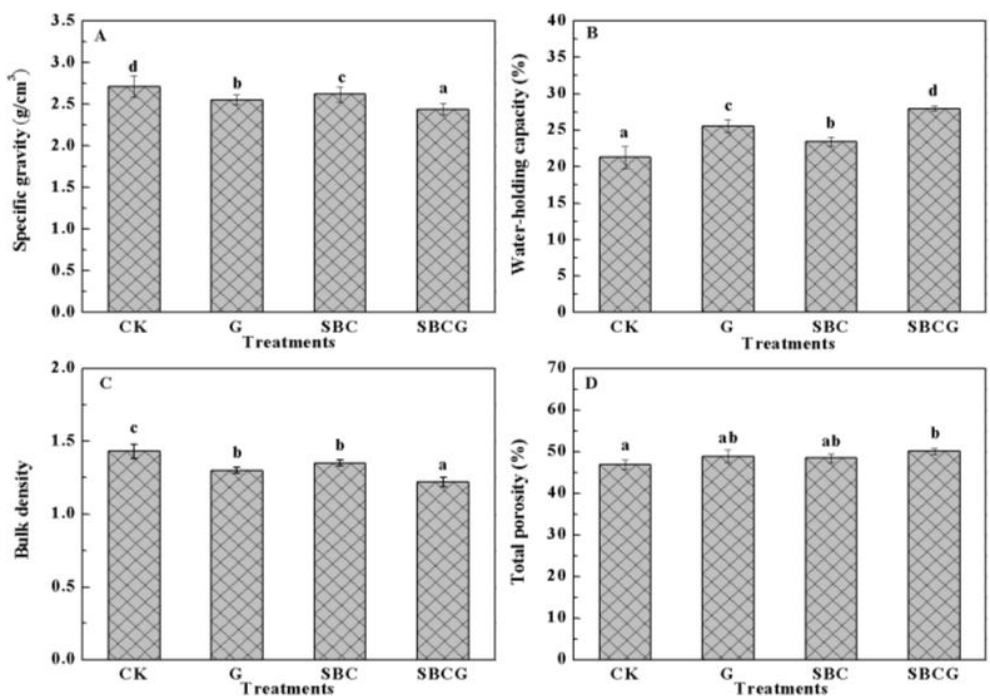

Figure 1. The physical properties ((A-D) stand for specific gravity, water-holding capacity, bulk density, total porosity, respectively) of ion-adsorption clay (IAC) mining wasteland soil in the un-amended control (CK), alfalfa revegetation (G), sludge biochar amendment (SBC) and combined amendment (SBCG) treatments. Different characters, a, b, c, and d, were used to indicate significant differences at $p<0.05$. Vertical bars indicate standard deviation.

\subsubsection{Effect on Soil Chemical Properties}

The soil chemical properties of the four treatments, including soil $\mathrm{pH}$, electrical conductivity, organic matter, total nitrogen, $\mathrm{C} / \mathrm{N}$, available nitrogen, available phosphorus and available potassium, are shown in Figure 2. The SBC and SBCG treatments had significantly higher $\mathrm{pH}$ than CK $(p<0.05)$, indicating the significantly acidic decrease in soils from IAC mining wastelands for sludge biochar application $(p<0.05)$.
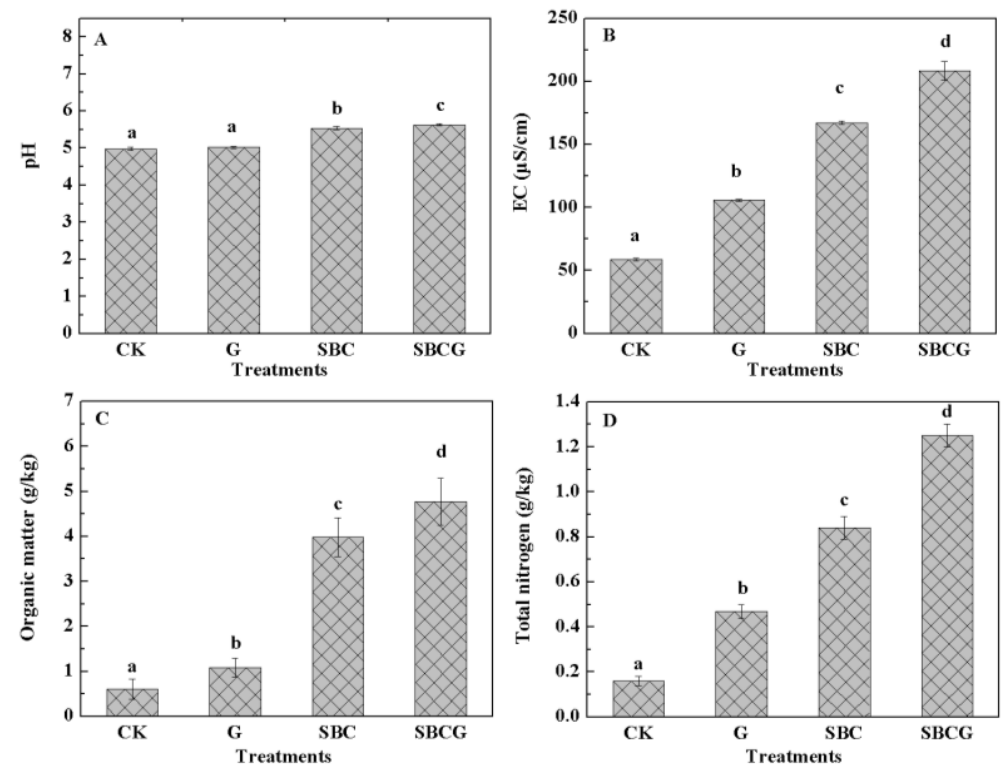

Figure 2. Cont. 

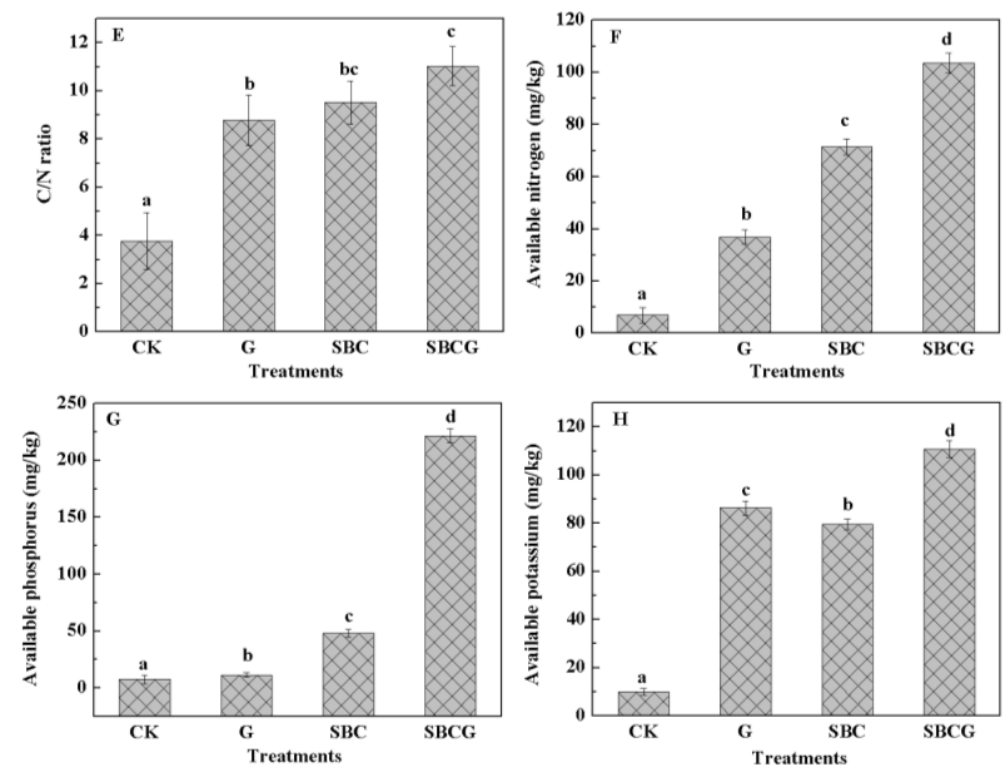

Figure 2. The chemical properties ((A-H) stand for $\mathrm{pH}$, electrical conductivity, organic matter, total nitrogen, $\mathrm{C} / \mathrm{N}$ ratio, available nitrogen, available phosphorus, available potassium, respectively) of IAC mining wasteland soil in the un-amended control (CK), alfalfa revegetation (G), sludge biochar amendment (SBC), and combined amendment (SBCG) treatments. Different characters, a, b, c, and d were used to indicate significant differences at $p<0.05$. Vertical bars indicate standard deviation.

The effect of sludge biochar on soil $\mathrm{pH}$ was attributed to the relatively high $\mathrm{pH}(6.17 \pm 0.03)$, which is higher than that of municipal sludge $(5.64 \pm 0.18)$ but lower than in most biochars $(>8.0)[59,60]$. In the slow pyrolysis process, many cations (such as $\mathrm{Ca}^{2+}, \mathrm{Mg}^{2+}, \mathrm{K}^{+}$and $\mathrm{Na}^{+}$) form carbonates or oxides, and can reduce soil acidity [61] when sludge biochar is applied to soil, which is consistent with the effects of biochar on strongly acidic soils $[62,63]$. EC, organic matter, total nitrogen, available nitrogen, and available phosphorus in treated soil (G, SBC, and SBCG) increased significantly, by 0.8-2.6 times, 78.6\%-6.82 times, 1.9-6.8 times, 4.3-13.8 times, and 0.5-27.8 times, respectively, over $\mathrm{CK}$ values, and the highest values were in the SBCG treatment. The difference in C/N ratio between SBCG (11.03 \pm 0.81$)$ and CK $(3.77 \pm 1.17)$ was significant $(p<0.05)$ but that between $\mathrm{G}$ and SBC was not $(p>0.05)$. Available potassium increased from $9.91 \pm 0.42$ in CK to $86.30 \pm 0.86,79.55 \pm 1.17$ and $110.79 \pm 0.44$ in the G, SBC, and SBCG treatments, respectively. This suggested that alfalfa revegetation and sludge biochar amendment significantly increased the contents of soil organic matter, nutrients and their availability (available nitrogen, available phosphorus and available potassium levels) $(p<0.05)$. Our results are consistent with the effects of biochar use and alfalfa revegetation on soil chemical properties from other reports. Many studies have demonstrated that the use of biochar can significantly increase soil organic $C[64,65]$, mineral nutrient content (e.g., N, P, K) [66] and the cation exchange capacity of soil [18] for its carbon-rich and porous structure [56] and huge specific surface area [67]. Increasing quantities of data have shown that alfalfa revegetation can significantly increase soil soil organic carbon and total nitrogen concentrations present in the root ball [68], C/N ratio [57], porosity, aeration conditions, and water-holding capacity [49], all of which could accelerate the mineralization of organic carbon and the release of mineral nutrients from sludge biochar, and in turn promote the alfalfa growth. In the present study, an additive effect on soil chemical properties, like that of soil physical properties, was also detected when combined sludge biochar amendment and alfalfa revegetation (Figure 2). 


\subsection{Response of Soil Microbial Community to Alfalfa Revegetation and Sludge Biochar Amendment}

\subsubsection{Soil Microbial Alpha Diversity}

After de-multiplexing and quality filtering, 468,000 and 360,000 high-quality bacterial and fungal sequences for each treatment were obtained for further analysis, and the results were shown in Table 3 .

Table 3. Summary of the number of bacterial and fungal sequences, number of operational taxonomic units (OTUs), $\alpha$-diversity indices (based on 97\% OTUs) and coverage in four treatments (mean $\pm \mathrm{S}$. V. (standard deviation), $n=3$ ).

\begin{tabular}{|c|c|c|c|c|c|}
\hline Microbial Group & Indices & CK & G & SBC & SBCG \\
\hline \multirow{4}{*}{ Bacteria } & $\mathrm{ACE}$ & $3220 \pm 395 a$ & $3366 \pm 192 \mathrm{a}$ & $3270 \pm 221 \mathrm{a}$ & $3430 \pm 157 \mathrm{a}$ \\
\hline & Shannon & $3.55 \pm 0.04 \mathrm{a}$ & $4.89 \pm 0.02 c$ & $4.62 \pm 0.02 b$ & $4.98 \pm 0.07 c$ \\
\hline & Simpson & $0.092 \pm 0.00 \mathrm{~d}$ & $0.020 \pm 0.00 \mathrm{c}$ & $0.028 \pm 0.00 \mathrm{c}$ & $0.017 \pm 0.00 \mathrm{~b}$ \\
\hline & Coverage & $0.99 \pm 0.00 \mathrm{a}$ & $0.98 \pm 0.00 \mathrm{~b}$ & $0.98 \pm 0.00 \mathrm{a}$ & $0.98 \pm 0.00 \mathrm{a}$ \\
\hline \multirow{5}{*}{ Fungi } & $\mathrm{ACE}$ & $1074 \pm 107 \mathrm{a}$ & $1558 \pm 27 b$ & $1085 \pm 89 a$ & $1798 \pm 69 b$ \\
\hline & Chao 1 & $752 \pm 42 \mathrm{a}$ & $1093 \pm 111 b$ & $1079 \pm 131 b$ & $1157 \pm 52 b$ \\
\hline & Shannon & $1.96 \pm 0.07 \mathrm{a}$ & $3.07 \pm 0.02 b, c$ & $2.72 \pm 0.07 \mathrm{~b}$ & $3.32 \pm 0.02 c$ \\
\hline & Simpson & $0.340 \pm 0.02 b$ & $0.107 \pm 0.00 \mathrm{a}$ & $0.140 \pm 0.00 \mathrm{a}$ & $0.011 \pm 0.00 \mathrm{a}$ \\
\hline & Coverage & $0.99 \pm 0.00 \mathrm{a}$ & $0.99 \pm 0.00 \mathrm{a}$ & $0.99 \pm 0.00 \mathrm{a}$ & $0.98 \pm 0.00 \mathrm{a}$ \\
\hline
\end{tabular}

Note: Different letters (such as a, b, c, d) within a row indicate significant differences $(p<0.05)$.

The mean length of bacterial and fungal sequences of all samples was 229.99 and $208.67 \mathrm{bp}$, respectively. The number of bacterial and fungal OTUs as well as ACE, Chao1 and Shannon indices among the four treatments were $\mathrm{CK}<\mathrm{SBC}<\mathrm{G}<\mathrm{SBCG}$, whereas the Simpson index showed an opposite trend: $\mathrm{CK}>\mathrm{SBC}>\mathrm{G}>\mathrm{SBCG}$. This indicated that alfalfa revegetation and sludge biochar amendment significantly increased soil microbial diversity in IAC mining wastelands $(p<0.05)$, with an additive effect generated by their combined amendment. The results were in accordance with previous studies in biochar-enriched Terra preta soils [69,70] and alfalfa amended soils [71,72]. This increased microbial diversity might be due to the supply of a more comfortable habitats, many nutrients or mineralized organic matter from sludge biochar [6,73] and root exudates of alfalfa [74]. Across all soil samples, the gene coverage was more than 0.98 , indicating that the sequencing results were representative.

\subsubsection{Soil Microbial Community Structure}

We detected 5927 OTUs in bacterial communities across all four treatments, for a total of 24 phyla, 48 classes, 97 orders, 236 families, and 737 genera. As shown in Figure 3a, the bacterial communities at the phylum level varied among the four treatments. The relative abundances of dominant bacteria ranked as follows: Proteobacteria $>$ Actinobacteria $>$ Firmicutes $>$ Bacteroidetes $>$ Acidobacteria > Verrucomicrobia > Planctomycetes. These seven phyla accounted for more than $97 \%$ gene sequences of soil in each treatment, with the respective proportion of $58.96 \%, 14.10 \%, 10.31 \%$, $8.73 \%, 2.53 \%, 2.03 \%$, and $0.88 \%$ in total. Alfalfa revegetation (G), sludge biochar amendment (SBC), and the combined amendment (SBCG) significantly reduced the relative abundances of Proteobacteria, and Firmicutes in soil of IAC mining wastelands $(p<0.05)$, whereas significantly increased abundances of Actinobacteria, Bacteroidetes, and Verrucomicrobia $(p<0.05)$.

The results were in agreement with other reports showing that Proteobacteria, Actinobacteria and Firmicutes were the main phyla in biochar [75-77] and alfalfa [78,79] amended soil, with the relative abundance of Proteobacteria decreased in biochar treated soil [77]. In addition, Actinobacteria was demonstrated to be the representative specie in recalcitrant carbon-rich soils like Terra preta [70] and pyrogenic carbon-treated soils [80], which explained the increased abundance of Actinobacteria in our study. 
We detected 2974 OTUs in fungal community across all four treatments, for a total of 6 phyla, 24 classes, 72 orders, 154 families, 280 genera, and 368 species. The relative abundance of fungal community at the phylum level varied among the four treatments (Figure $3 b$ ). The relative abundances of dominant fungi ranked as follows: Ascomycota $>$ Basidiomycota $>$ Zygomycota $>$ Chytridiomycota $>$ Glomeromycota. The five phyla accounted for more than $50 \%$ gene sequences of soil in each treatment, with the respective proportion of $50.14 \%, 1.72 \%, 0.22 \%, 0.05 \%$ and $0.005 \%$ in total.

The results were quite similar to the findings in a previous study [81], which showed that Ascomycota, Basidiomycota, and Zygomycota were the dominant fungal phyla across all soil samples while Chytridiomycota and Glomeromycota were minor phyla. Alfalfa revegetation (G), sludge biochar amendment (SBC), and the combined amendment (SBCG) significantly elevated the relative abundance of Ascomycota in the soil of IAC mining wastelands $(p<0.05)$, and significantly reduced that of Basidiomycota $(p<0.05)$. At the genus level, there was a total of 737 bacterial genera (Figure 4a) detected in four treatments, with different patterns of dominance. Alfalfa revegetation, sludge biochar amendment, and the combined amendment significantly elevated the relative abundances of Arthrobacter, Burkholderia. Devosia, Edaphobacter, Leifsonia, Massilia, Mucilaginibacter, Sinomonas, Sphingomonas and Stenotrophomonas in soil $(p<0.05)$, whereas significantly reduced abundances of Exiguobacterium, Citrobacter, Pseudomonas, and Bradyhizobium $(p<0.05)$. Arthrobacter, an gram-negative bacterium, was demonstrated to have the ability to degrade hydrocarbons and its' higher relative abundance was detected in biochar [82,83] and alfalfa-amended soil [84]. Sphingobium was reported to increase in soil treated with biochar, and can degrade recalcitrant compounds [85]. A total of 280 fungal genera, including 368 species, were detected across four treatments, with different patterns of dominance (Figure 4 b). Alfalfa revegetation, sludge biochar amendment, and the combined amendment significantly enhanced the relative abundances of unclassified_Nectriaceae, unclassified_Sordariomycetes, Penicillium, Humicola, unclassified_Chaetomiaceae, and Myrothecium $(p<0.05)$, whereas significantly decreased that of Aspergillus, unclassified_Capnodiales, unclassified_Agaricostilbaceae, Clonostachys, unclassified_Ascomycota, unclassified_Pleosporaceae, and unclassified_Davidiellaceae $(p<0.05)$. Our results were in accord with the relative abundance change of fungal community in biochar $[76,86,87]$ and alfalfa $[79,88]$ amended soil.

PCoA (Figure 5) and hierarchical cluster heat-map analysis (Figure 6) revealed the similarity and differences of bacterial and fungal communities in the four treatments at the genus level. The results of PCoA showed that PCoA 1, PCoA 2, and PCoA 3 explained $82.9 \%, 10.6 \%$, and 2.9\%, respectively, as well as $57.9 \%, 26.7 \%$, and $9 \%$, respectively, differences of bacterial (Figure $5 \mathrm{a}$ ) and fungal (Figure $5 \mathrm{~b}$ ) community structure in soil. Heat-map analysis suggested that for bacterial communities (Figure 6a), CK treatment alone formed its own cluster and the three amendment treatments (G, SBC, and SBCG) formed a separate cluster, indicating the similarity of amendment treatments (G, SBC, and SBCG) and the differences between amended (G, SBC, and SBCG) and un-amended (CK) treatments. For fungal communities (Figure 6b), CK and G were clustered together while SBC and SBCG were clustered together, indicating that sludge biochar amendment had a greater effect on soil fungal community than alfalfa revegetation. 


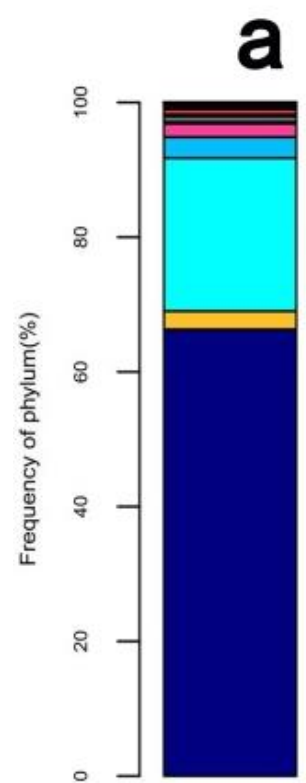

CK

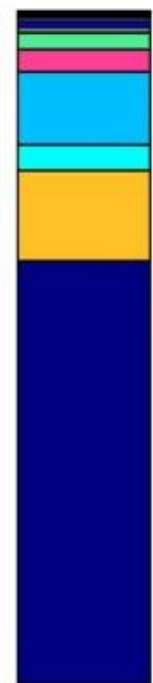

G

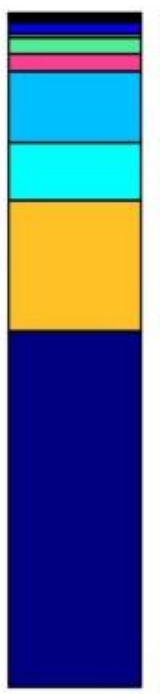

SBC

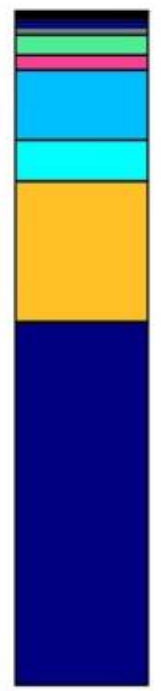

SBCG

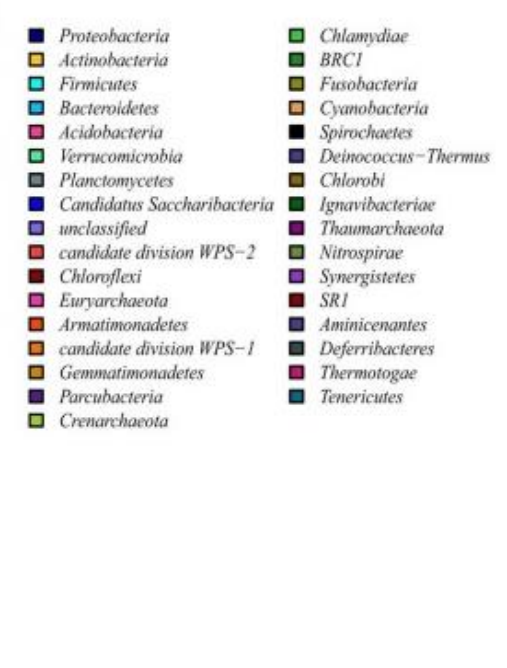

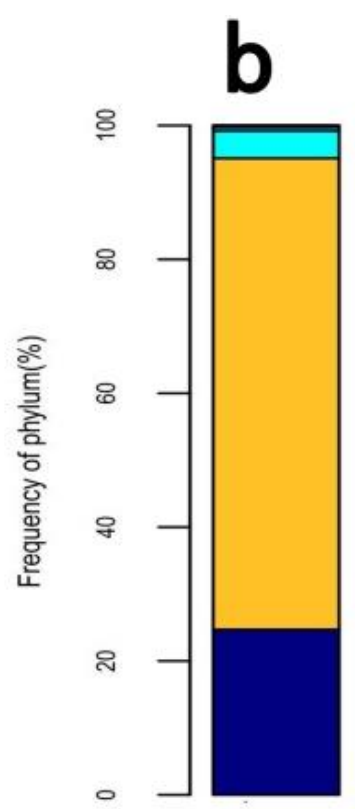

CK

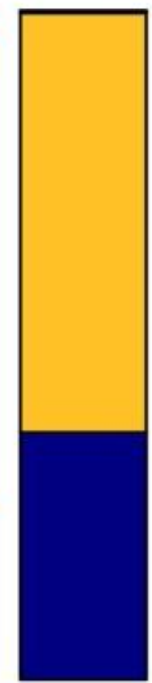

G

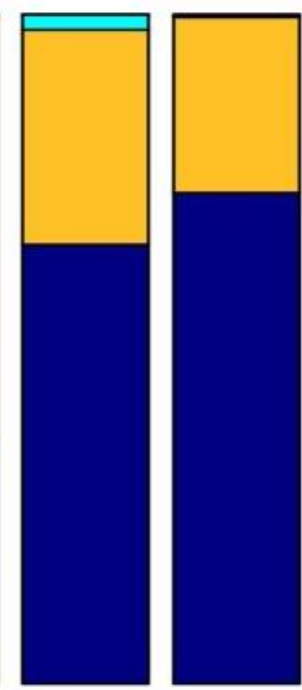

SBC

SBCG

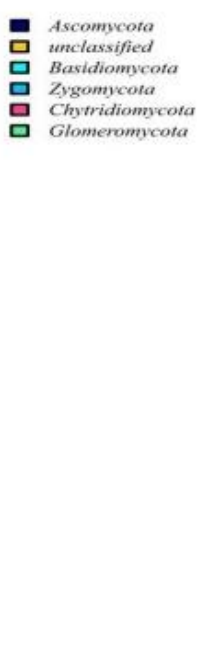

Figure 3. Frequency of bacterial (a) and fungal (b) phyla detected in IAC mining wasteland soil in the un-amended control (CK), alfalfa revegetation (G), sludge biochar amendment (SBC), and combined amendment (SBCG) treatments. Abundance is presented in terms of the average percentage, classified by Ribosomal Database Project (RDP) classifier at a confidence threshold of $80 \%$. "Other" refers to the sum of unclassified sequences and all other taxa with abundances $<0.9 \%$ in any sample. 
a

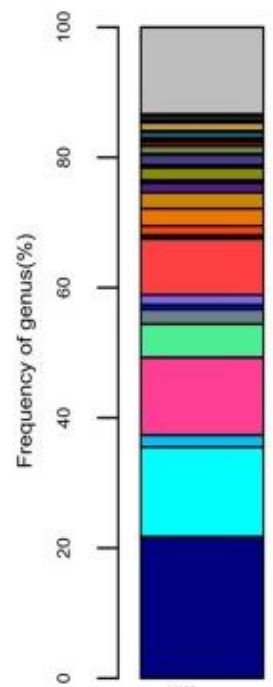

CK

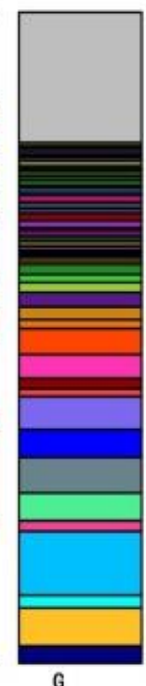

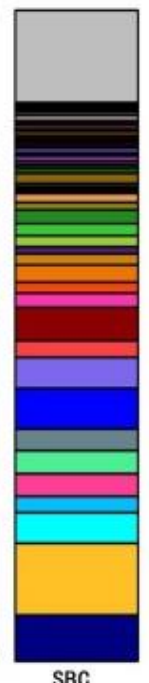
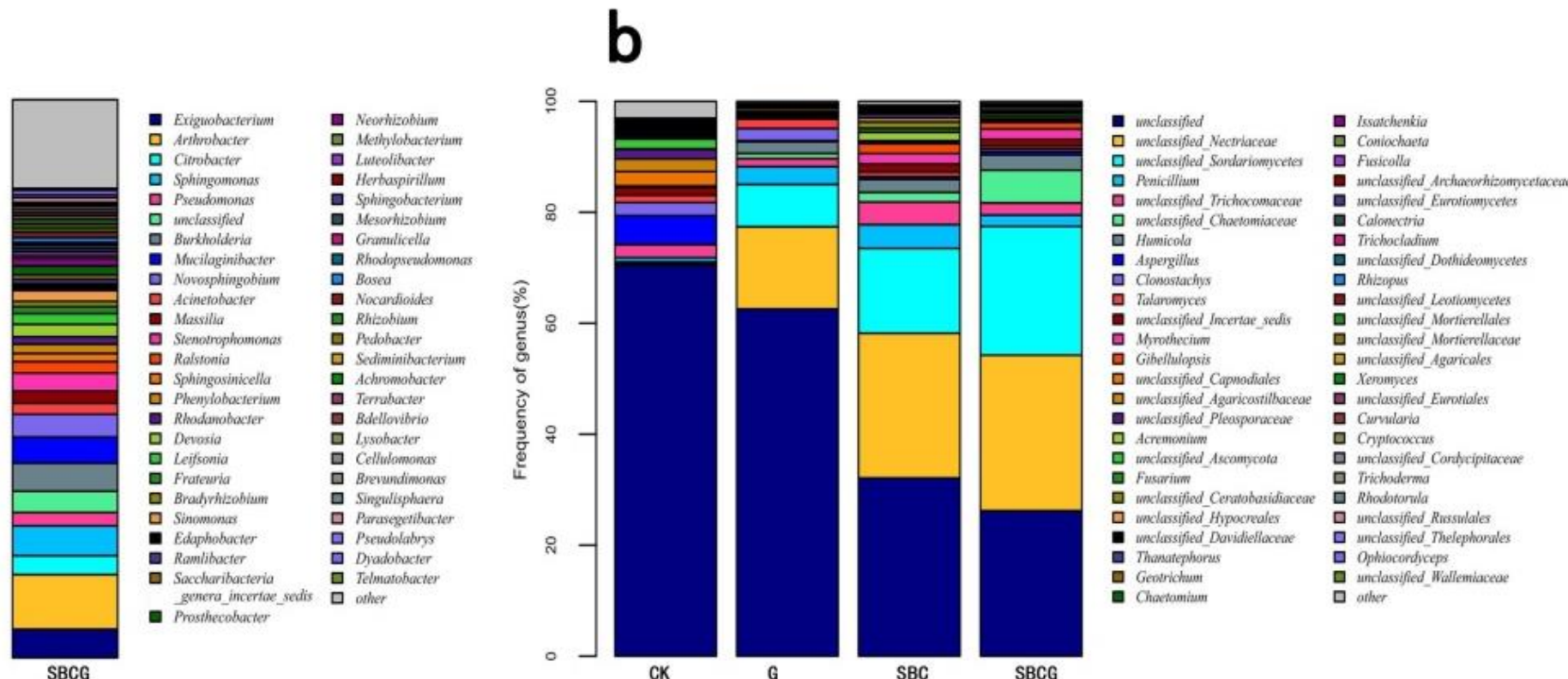

Figure 4. Frequency of bacterial (a) and fungal (b) genera detected in IAC mining wasteland soil in the un-amended control (CK), alfalfa revegetation (G), sludge biochar amendment (SBC), and combined amendment (SBCG) treatments. Abundance is presented in terms of the average percentage, classified by RDP classifier at a confidence threshold of $80 \%$. "Other" refers to the sum of unclassified sequences and all other taxa with abundances $<0.9 \%$ in any sample. 

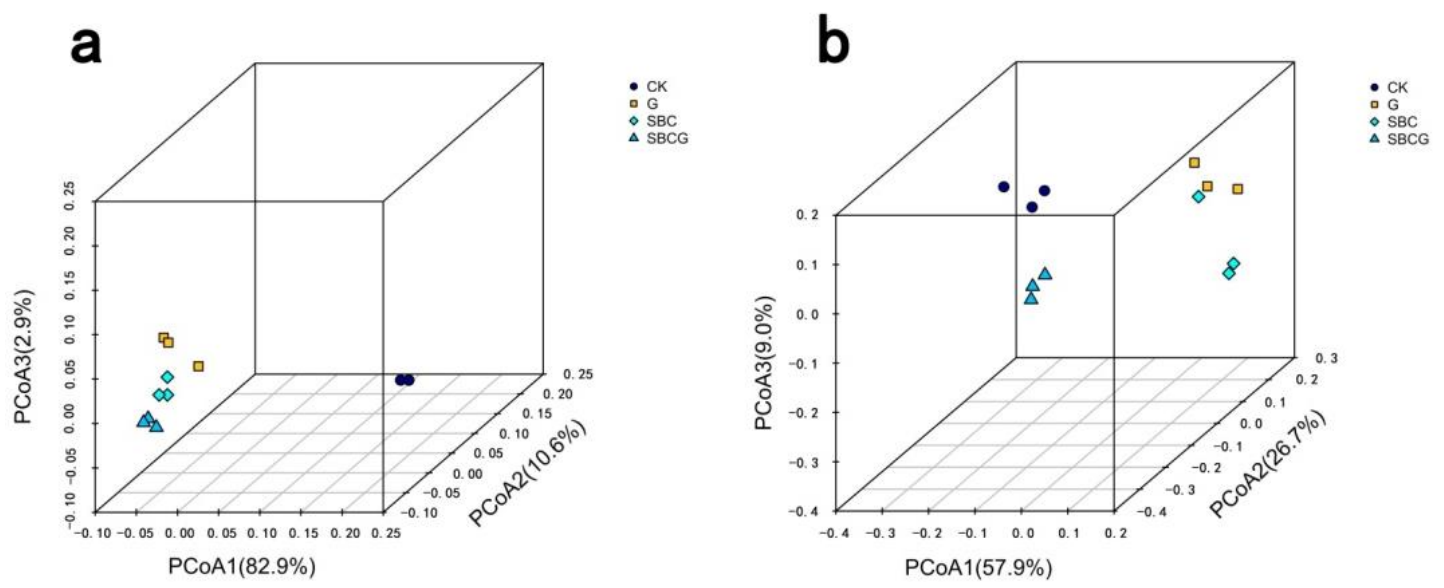

Figure 5. Principal coordinate analysis of bacterial (a) and fungal (b) genera in IAC mining wasteland soil in the un-amended control $(\mathrm{CK})$, alfalfa revegetation $(\mathrm{G})$, sludge biochar amendment (SBC), and combined amendment (SBCG) treatments.
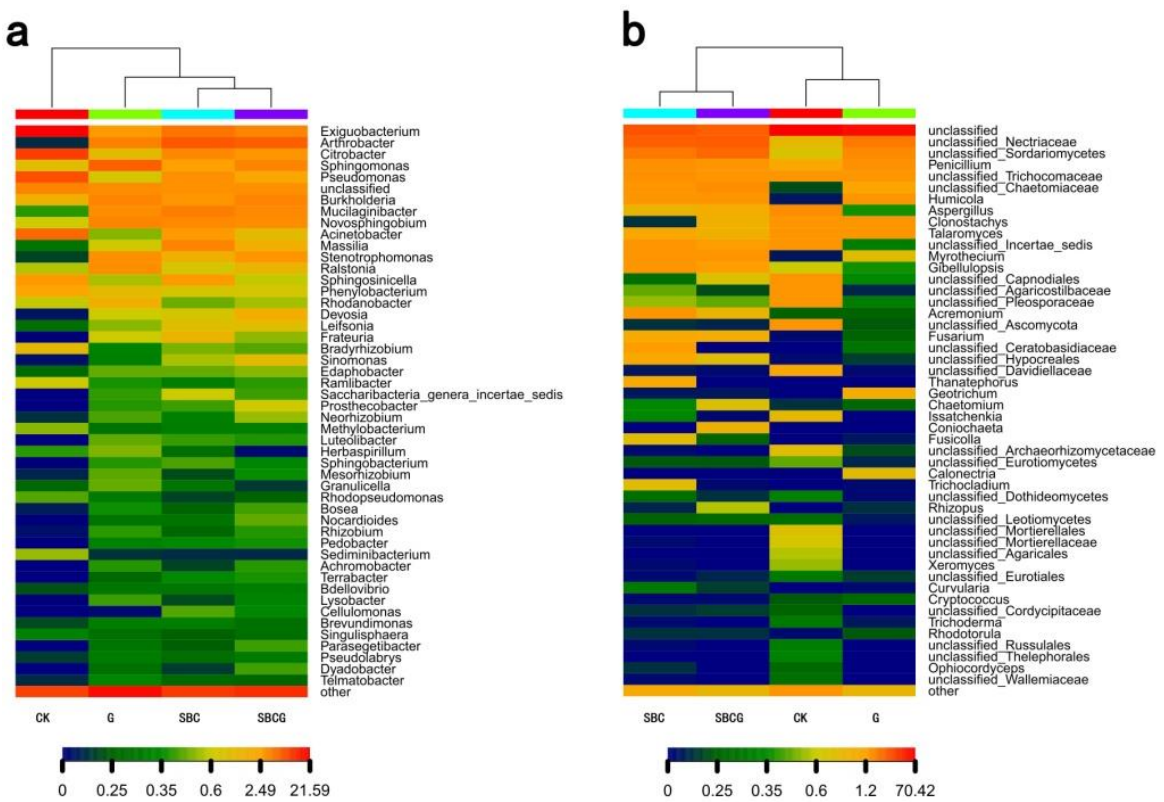

Figure 6. Heat-map based on bacterial (a) and fungal (b) community composition (at the genus level) in IAC mining wasteland soil in the un-amended control (CK), alfalfa revegetation (G), sludge biochar amendment (SBC), and combined amendment (SBCG) treatments.

Our results suggested the significant change of bacterial and fungal communities' compositions for sludge biochar application and alfalfa revegetation, which were in agreement with previous studies. Organic amendments were demonstrated to be the most important means of managing soil biodiversity, and their quantity, quality, and distribution each affected the trophic structure of the soil food web $[89,90]$. Sludge biochar and root exudates of alfalfa both provided organic matter for soil microbes' growth. Generally, the amount of soil organic matter from sludge biochar was larger than that from root exudates of alfalfa, which were in agreement with the much higher organic matter value of SBC than of G (Figure 2). Additionally, fungi were known to be saprophytes, associated with degradable soil organic matter [91]. Normally, soil organic matter was successively utilized by bacteria and fungi. All the aforementioned could explain the bacterial difference between control (CK) and treated soils ( $G, S B C, S B C G)$ as well as the fungal difference between sludge biochar amended (SBC and SBCG) and un-amended soils (CK and G). 
3.3. The Complex Relationship between Soil Physicochemical Properties and Microbial Communities, and the Response of Plant Growth to Remediation

\subsubsection{Redundancy Analyses of Soil Physicochemical Properties and Microbial Community}

Redundancy analyses between soil properties and bacterial and fungal community structure were conducted and a bi-plot is shown in Figure 7. The investigated soil physicochemical properties could explain $98.9 \%$ and $99.0 \%$ of the variation of bacterial and fungal community structure (Table 4), respectively. All soil physicochemical properties (except available phosphorus) had a significant impact on bacterial community structure $(p<0.05)$. The effects of available potassium, $\mathrm{pH}, \mathrm{C} / \mathrm{N}$, bulk density, water-holding capacity, specific gravity, EC, total nitrogen, and total porosity were significant $(p<0.01)$. All soil physicochemical properties had a significant influence on fungal community $(p<0.05)$. The effects of $\mathrm{pH}$, available potassium, $\mathrm{C} / \mathrm{N}, \mathrm{EC}$, available nitrogen, total nitrogen, organic matter, and bulk density were significant $(p<0.01)$. The variation in the bacterial community explained by the soil physicochemical properties decreased as follows: available potassium $>\mathrm{pH}>\mathrm{C} / \mathrm{N}>$ bulk density $>$ water-holding capacity $>$ specific gravity $>\mathrm{EC}>$ available nitrogen $>$ total nitrogen $>$ organic matter $>$ total porosity $>$ available phosphorus. Furthermore, available potassium, $\mathrm{pH}, \mathrm{C} / \mathrm{N}$, organic matter, bulk density, and total porosity could be used to explain $93.6 \%$ variation of the bacterial community data, and were confirmed to be the key environmental factors. The variation in fungal community explained by soil physicochemical properties decreased as follows: $\mathrm{pH}>$ available potassium $>$ $\mathrm{C} / \mathrm{N}>\mathrm{EC}>$ available nitrogen $>$ total nitrogen $>$ organic matter $>$ bulk density $>$ water-holding capacity $>$ specific gravity $>$ total porosity $>$ available phosphorus. Moreover, available potassium, $\mathrm{pH}$, organic matter, $\mathrm{C} / \mathrm{N}$, bulk density, and total porosity could be used to explain $88.0 \%$ variation of fungal community data, and were confirmed to be the critical environmental factors. In general, the key environmental factors affecting bacterial community were similar to those affecting the fungal community.

Table 4. Results of the Monte Carlo permutation test for bacterial and fungal community variation explained by soil physicochemical properties.

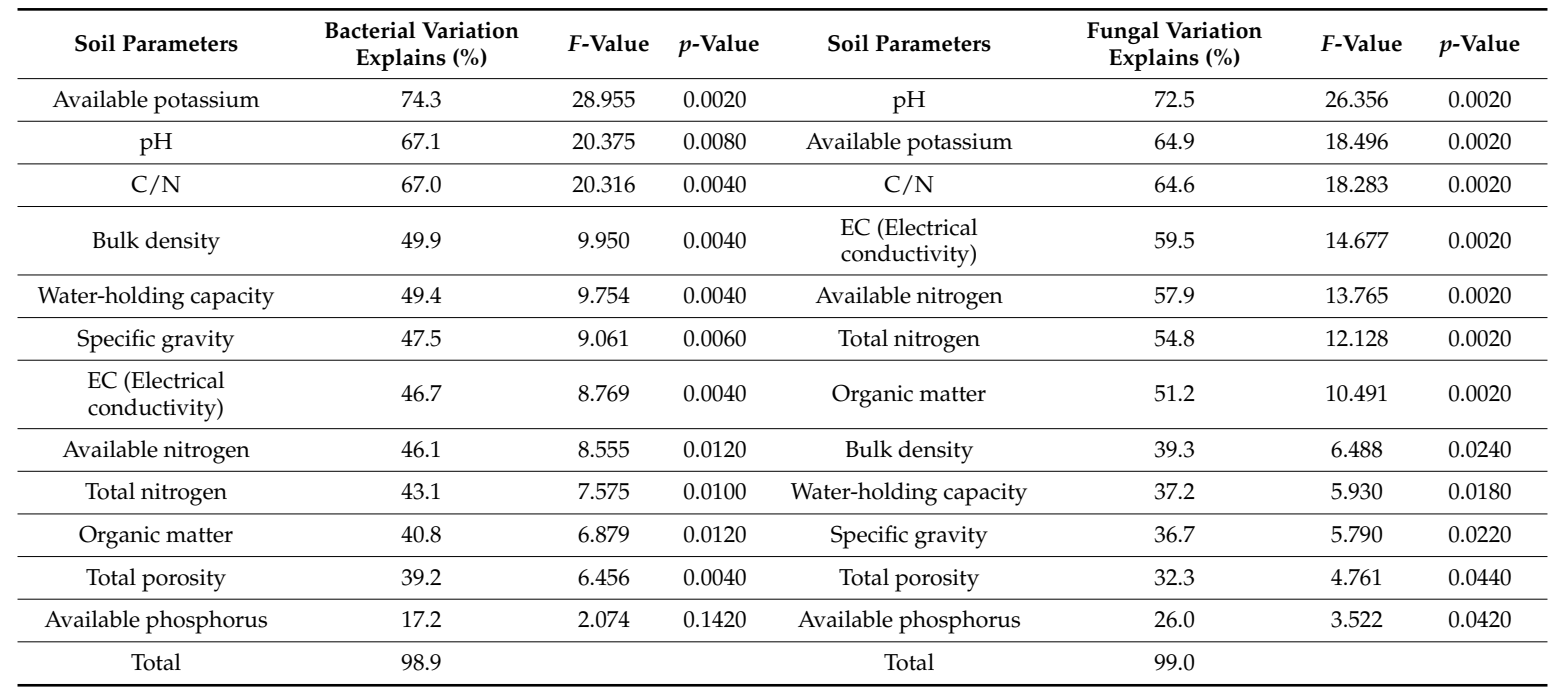

Our results suggested that alfalfa revegetation could enhance soil microbial community diversity and richness of IAC mining wastelands, which are similar to the results of Chen [92]. Alfalfa revegetation significantly improved soil physicochemical properties, including enhancement of soil porosity, water-holding capacity and content of organic matter and nutrients (e.g., N, P, and K), decrease of soil bulk density, and amelioration of soil structure, all of which were helpful to the proliferation of soil microorganisms (bacteria and fungi). Sludge biochar amendment also enhanced the diversity and richness 
of the microbial community in IAC mining wasteland soil. This is because biochar not only provides several types of nutrients (C, N, and other trace elements) for soil microbial growth [93], but will also ameliorate the soil environment for microbial proliferation, by for example reducing soil acidity, elevating soil porosity, and improving soil aeration conditions [94]. These claims are consistent with the results of biochar on microbiota in acidic soil $[76,95]$. Additionally, due to its porous structure, large specific surface area and cation exchange capacity, biochar has the ability to retain nutrients [96] and would provide them to the soil after oxidation. The combination of alfalfa revegetation and sludge biochar amendment further enhanced the diversity and richness of the soil microbial community in IAC mining wastelands. This is because sludge biochar not only directly increases soil microbial diversity and richness, but also benefits alfalfa growth to affect soil microbiota. The aromatic hydrocarbon structure contributes to the long-term retention of sludge biochar in soils [18], and thus provides nutrients continuously to soil after its oxidation.

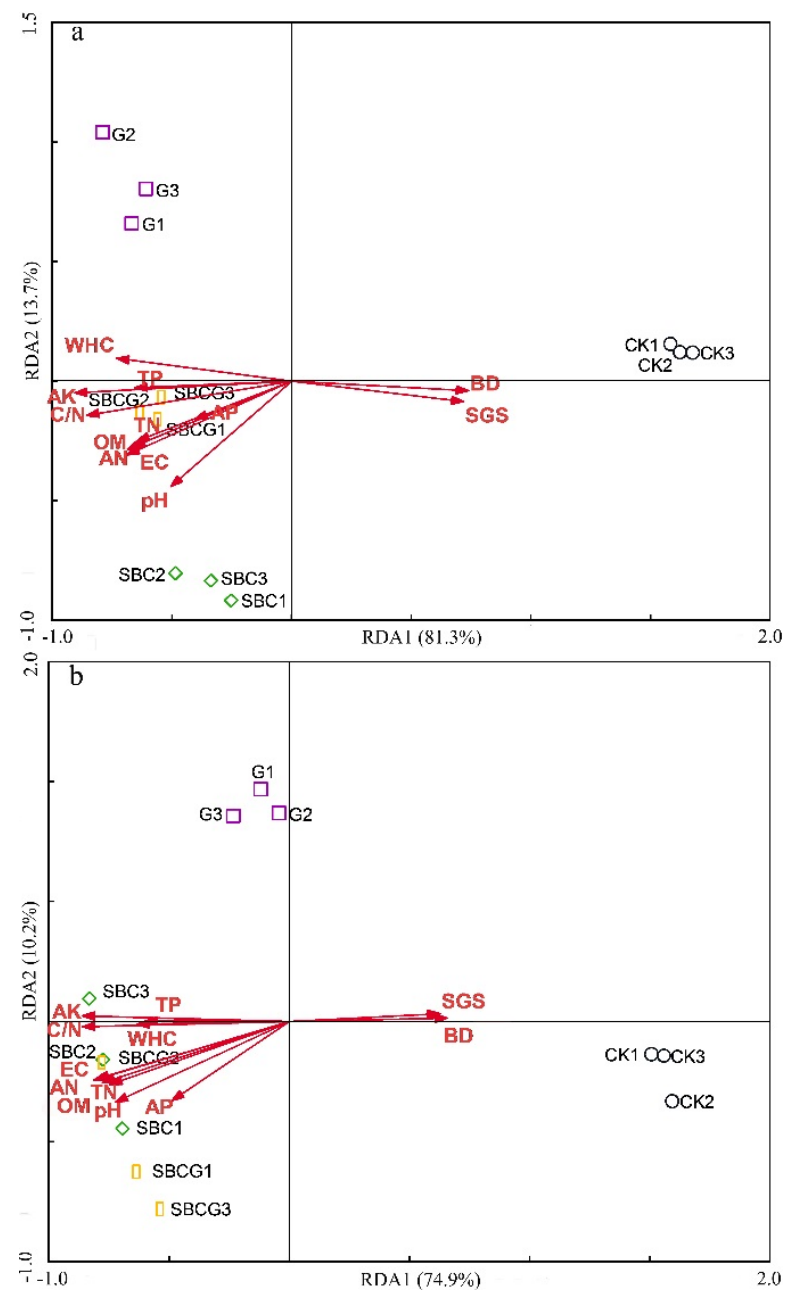

Figure 7. Redundancy analysis (RDA) between soil bacterial communities (a) or fungal communities (b) and environmental factors in the four different treatments: un-amended control (CK), alfalfa revegetation $(\mathrm{G})$, sludge biochar amendment (SBC), and combined amendment (SBCG) treatments.

\subsubsection{Responses of Plant Growth and Root Morphology}

Alfalfa growth (Figure 8a) and its root morphology (Figure 8b) in the G and SBCG treatments differed. Alfalfa growth in the sludge biochar amendment treatment (SBCG) was significantly better than the alfalfa-only treatment $(G)$ (Figure 8a). Plant height, shoot biomass, root biomass, and total biomass were significantly higher in SBCG than in G (Table 5). The root segment of alfalfa had similar 
results, and TRL, RSA, RV (root volume, see Part 2.5), RAD, RTN, and RFN of SBCG were significantly larger than those of $\mathrm{G}$ (Table $6, p<0.05$ ).

Sludge biochar application could continuously ameliorate the soil environment (physicochemical properties) of IAC mining wastelands. It may reduce soil acidity, specific gravity, and bulk density, improve soil texture and ventilation conditions, enhance soil porosity, water-holding capacity, the content and effectiveness of nutrients, and change the microbial community structure to promote the growth of alfalfa $[97,98]$.

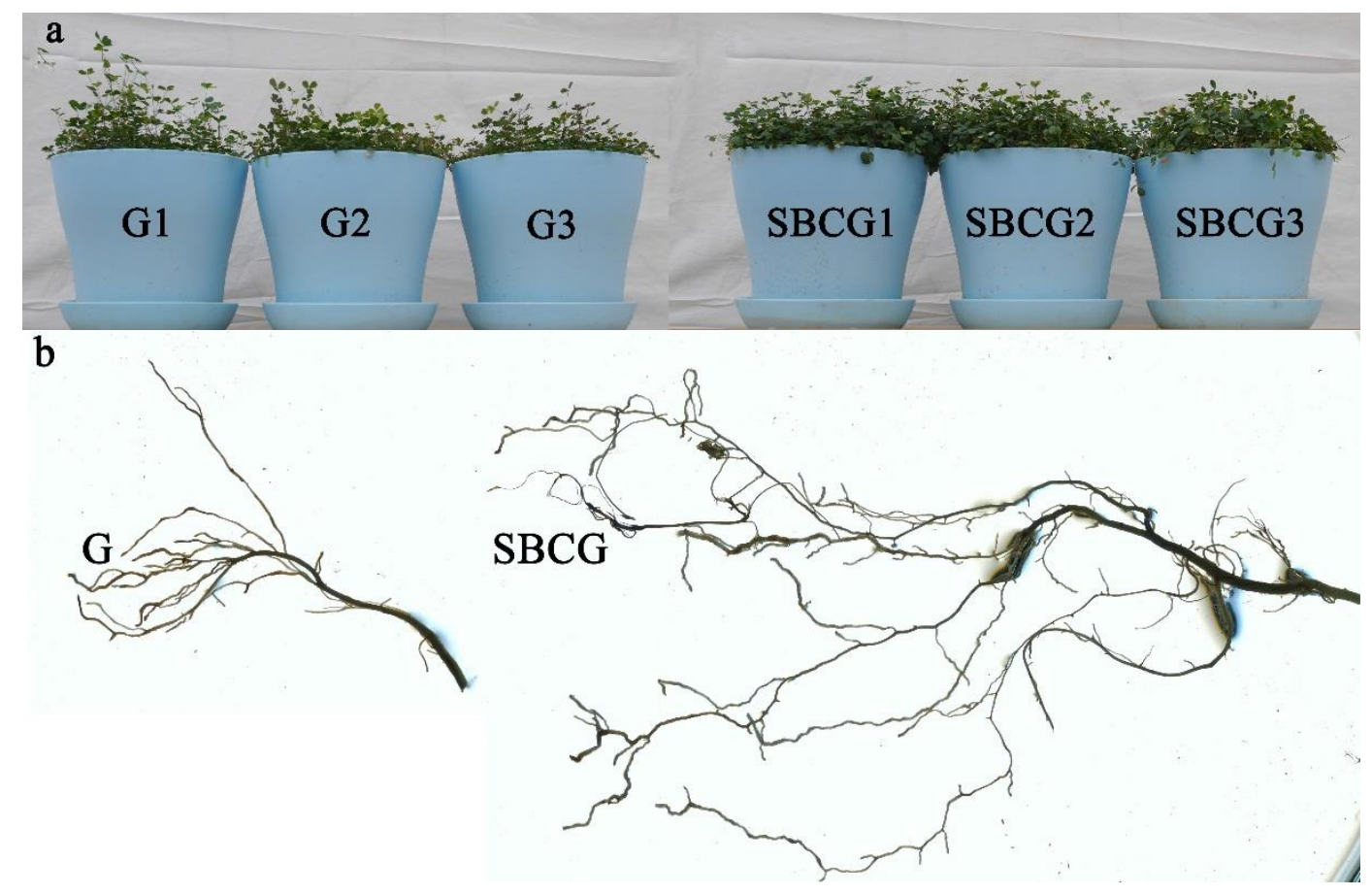

Figure 8. Alfalfa growth (a) and root morphology (b) in the alfalfa revegetation $(G)$ and combined alfalfa and sludge biochar amendment (SBCG) treatments.

Table 5. The plant height, root length, shoot biomass, root biomass, and total biomass of alfalfa after incubation (mean \pm S.V. (standard deviation), $n=3$ ).

\begin{tabular}{ccccc}
\hline Treatments & Plant Height $(\mathbf{c m})$ & Shoot Biomass $(\mathrm{g})$ & Root Biomass $\mathbf{( g )}$ & Total Biomass $(\mathrm{g})$ \\
\hline G & $8.98 \pm 0.24 \mathrm{a}$ & $5.36 \pm 0.35 \mathrm{a}$ & $8.53 \pm 0.03 \mathrm{a}$ & $13.89 \pm 0.34 \mathrm{a}$ \\
SBCG & $11.09 \pm 0.15 \mathrm{~b}$ & $7.64 \pm 0.26 \mathrm{~b}$ & $11.55 \pm 0.04 \mathrm{~b}$ & $19.20 \pm 0.22 \mathrm{~b}$ \\
\hline
\end{tabular}

Different letters within each column indicate significant differences $(p<0.05)$. G, soil planted with alfalfa; SBCG, soil amended with $5 \%(w / w)$ sludge biochar and planted with alfalfa. Shoot, root and total biomass of alfalfa were dry weight biomass as stated in Section 2.5 .

Table 6. Summary of root growth indices of alfalfa after incubation (mean \pm S.V. (standard deviation), $n=3)$.

\begin{tabular}{ccccccc}
\hline Treatments & TRL $(\mathbf{c m})$ & RSA $\left(\mathbf{c m}^{\mathbf{2}}\right)$ & RV $\left(\mathbf{c m}^{\mathbf{3}}\right)$ & RAD $(\mathbf{m m})$ & RTN & RFN \\
\hline G & $96.70 \pm 1.79 \mathrm{a}$ & $12.05 \pm 1.17 \mathrm{a}$ & $0.19 \pm 0.04 \mathrm{a}$ & $0.46 \pm 0.02 \mathrm{a}$ & $161.67 \pm 5.36 \mathrm{a}$ & $293.00 \pm 6.56 \mathrm{a}$ \\
SBCG & $120.67 \pm 4.35 \mathrm{~b}$ & $18.38 \pm 0.96 \mathrm{~b}$ & $0.53 \pm 0.04 \mathrm{~b}$ & $0.58 \pm 0.01 \mathrm{~b}$ & $249.00 \pm 5.69 \mathrm{~b}$ & $365.00 \pm 18.90 \mathrm{~b}$ \\
\hline
\end{tabular}

Different letters within each column indicate significant differences $(p<0.05)$. G, soil planted with alfalfa; SBCG, soil amended with $5 \%(w / w)$ sludge biochar and planted with alfalfa. TRL, total root length; RSA, root surface area; $\mathrm{RV}$, root volume; RAD, root average diameter; RTN, root tip number; RFN, root fork number. 


\section{Conclusions}

Alfalfa revegetation and sludge biochar amendment both improved soil physicochemical properties and enhanced the diversity and richness of the microbial community. In addition, the combined treatment (soil amended with alfalfa revegetation and biochar) resulted in the greatest improvement of soil physicochemical properties, the enhancement of diversity and richness of microbial community, and the promotion of plant growth. Redundancy analyses showed that soil physicochemical properties could explain $98.9 \%$ and $99 \%$ of the variation in bacterial and fungal community structure, respectively, and soil available potassium, $\mathrm{pH}$, organic matter, $\mathrm{C} / \mathrm{N}$ ratio, bulk density, and total porosity were the critical environmental factors affecting soil microbiota. Moreover, sludge biochar could be used to promote the growth of alfalfa and change their root morphology, which in turn accelerated the soil rehabilitation process of IAC mining wastelands. In this way, the combined amendment of alfalfa revegetation and sludge biochar amendment not only serve as soil remediation for IAC mining wastelands but also resolve the difficult problem of municipal sludge disposal by making the waste profitable. Thus, a combined strategy is recommended to achieve sustainable soil restoration for IAC mining wastelands.

Author Contributions: C.L., Y.D. and X.L. conceived and designed the experiments; C.L., J.L., S.Z. and Z.W. performed the experiments; C.L., X.L. and X.G. analyzed the data; C.L., K.I. and Y.D. wrote the paper. All authors have read and approved the final manuscript.

Funding: The present work was funded by the National Science and Technology Pillar Program of China during the Twelfth Five-year Plan Period (2012BAC11B07); National Science and Technology Benefiting Program of China (2013GS360203); “Gan Po 555 Project” Leading Talents Training Program, Outstanding Doctoral Dissertation Project Fund of Jiangxi University of Science and Technology (No: YB2016005); Innovation Special Fund for Graduates of Jiangxi Province (YC2014-B059); the Science and Technology Landing Plan of Jiangxi Province for Universities (KJLD14042); the Technology Support Plan of Jiangxi Province (20151BBG70005); and the National Natural Science Foundation of China (51564023); and the Recruitment Program of High-end Foreign Experts of the State Administration of Foreign Experts Affairs awarded to Kazuyuki Inubushi (GDW20177200147); and China Scholarship Council.

Acknowledgments: We thank LetPub (www.letpub.com) for its linguistic assistance during the preparation of this manuscript.

Conflicts of Interest: The authors declare no conflict of interest.

\section{References}

1. Xiao, Y.; Huang, L.; Long, Z.; Feng, Z.; Wang, L. Adsorption ability of rare earth elements on clay minerals and its practical performance. J. Rare Earths 2016, 34, 543-548. [CrossRef]

2. Yang, X.J.; Lin, A.; Li, X.-L.; Wu, Y.; Zhou, W.; Chen, Z. China's ion-adsorption rare earth resources, mining consequences and preservation. Environ. Dev. 2013, 8, 131-136. [CrossRef]

3. Luo, C.; Luo, X.; Su, J.; Chen, C.; Han, D. Environmental Problems and Treatment Measures in Ionic-type rare earth mine. Met. Mine 2014, 6, 91-96.

4. Initiative, I.B. Standardized Product Definition and Product Testing Guidelines for Biochar That is Used in Soil; International Biochar Initiative: Seattle, WA, USA, 2013.

5. Wu, H.; Lai, C.; Zeng, G.; Liang, J.; Chen, J.; Xu, J.; Dai, J.; Li, X.; Liu, J.; Chen, M.; et al. The interactions of composting and biochar and their implications for soil amendment and pollution remediation: A review. Crit. Rev. Biotechnol. 2017, 37, 754-764. [CrossRef] [PubMed]

6. Lehmann, J.; Rillig, M.C.; Thies, J.; Masiello, C.A.; Hockaday, W.C.; Crowley, D. Biochar effects on soil biota-A review. Soil Biol. Biochem. 2011, 43, 1812-1836. [CrossRef]

7. Singla, A.; Iwasa, H.; Inubushi, K. Effect of biogas digested slurry based-biochar and digested liquid on $\mathrm{N}_{2} \mathrm{O}$, $\mathrm{CO}_{2}$ flux and crop yield for three continuous cropping cycles of komatsuna (Brassica rapa var. perviridis). Biol Fert Soils 2014, 50, 1201-1209. [CrossRef]

8. Singla, A.; Dubey, S.K.; Singh, A.; Inubushi, K. Effect of biogas digested slurry-based biochar on methane flux and methanogenic archaeal diversity in paddy soil. Agric. Ecosyst. Environ. 2014, 19 (Suppl. C), 278-287. [CrossRef] 
9. Alpana, S.; Vishwakarma, P.; Adhya, T.K.; Inubushi, K.; Dubey, S.K. Molecular ecological perspective of methanogenic archaeal community in rice agroecosystem. Sci. Total Environ. 2017, 596 (Suppl. C), 136-146. [CrossRef] [PubMed]

10. Delwiche, K.B.; Lehmann, J.; Walter, M.T. Atrazine leaching from biochar-amended soils. Chemosphere 2014, 95 (Suppl. C), 346-352. [CrossRef] [PubMed]

11. Fungo, B.; Lehmann, J.; Kalbitz, K.; Tenywa, M.; Thionǵo, M.; Neufeldt, H. Emissions intensity and carbon stocks of a tropical Ultisol after amendment with Tithonia green manure, urea and biochar. Field Crops Res. 2017, 209 (Suppl. C), 179-188. [CrossRef] [PubMed]

12. Lentz, R.D.; Ippolito, J.A.; Spokas, K.A. Biochar and Manure Effects on Net Nitrogen Mineralization and Greenhouse Gas Emissions from Calcareous Soil under Corn. Soil Sci. Soc. Am. J. 2014, 78, 1641-1655. [CrossRef]

13. Castellini, M.; Giglio, L.; Niedda, M.; Palumbo, A.D.; Ventrella, D. Impact of biochar addition on the physical and hydraulic properties of a clay soil. Soil Tillage Res. 2015, 154, 1-13. [CrossRef]

14. Chen, B.; Yuan, M.; Qian, L. Enhanced bioremediation of PAH-contaminated soil by immobilized bacteria with plant residue and biochar as carriers. J. Soils Sediment. 2012, 12, 1350-1359. [CrossRef]

15. Fungo, B.; Guerena, D.; Thiongo, M.; Lehmann, J.; Neufeldt, H.; Kalbitz, $\mathrm{K}_{\text {. }} \mathrm{N}_{2} \mathrm{O}$ and $\mathrm{CH}_{4}$ emission from soil amended with steam-activated biochar. J. Plant Nutr. Soil Sci. 2014, 177, 34-38. [CrossRef]

16. Wang, B.; Lehmann, J.; Hanley, K.; Hestrin, R.; Enders, A. Adsorption and desorption of ammonium by maple wood biochar as a function of oxidation and pH. Chemosphere 2015, 138, 120-126. [CrossRef] [PubMed]

17. Liang, B.; Lehmann, J.; Solomon, D.; Kinyangi, J.; Grossman, J.; O’Neill, B.; Skjemstad, J.O.; Thies, J.; Luizão, F.J.; Petersen, J.; et al. Black Carbon Increases Cation Exchange Capacity in Soils. Soil Sci. Soc. Am. J. 2006, 70, 1719-1730. [CrossRef]

18. Khan, S.; Chao, C.; Waqas, M.; Arp, H.P.H.; Zhu, Y.-G. Sewage Sludge Biochar Influence upon Rice (Oryza sativa L.) Yield, Metal Bioaccumulation and Greenhouse Gas Emissions from Acidic Paddy Soil. Environ. Sci. Technol. 2013, 47, 8624-8632. [CrossRef] [PubMed]

19. Ro, K.S. Kinetics and Energetics of Producing Animal Manure-Based Biochar. BioEnergy Res. 2016, 9, 447-453. [CrossRef]

20. Waqas, M.; Li, G.; Khan, S.; Shamshad, I.; Reid, B.; Qamar, Z.; Chao, C. Application of sewage sludge and sewage sludge biochar to reduce polycyclic aromatic hydrocarbons $(\mathrm{PAH})$ and potentially toxic elements (PTE) accumulation in tomato. Environ. Sci. Pollut. Res. 2015, 22, 12114-12123. [CrossRef] [PubMed]

21. Lu, T.; Yuan, H.; Wang, Y.; Huang, H.; Chen, Y. Characteristic of heavy metals in biochar derived from sewage sludge. J. Mater. Cycles Waste Manag. 2016, 18, 725-733. [CrossRef]

22. Feng, L.; Luo, J.; Chen, Y. Dilemma of sewage sludge treatment and disposal in China. Environ. Sci. Technol. 2015, 49, 4781-4782. [CrossRef] [PubMed]

23. Yue, Y.; Yao, Y.; Lin, Q.; Li, G.; Zhao, X. The change of heavy metals fractions during hydrochar decomposition in soils amended with different municipal sewage sludge hydrochars. J. Soils Sediment. 2017, 17, 763-770. [CrossRef]

24. Bondarczuk, K.; Markowicz, A.; Piotrowska-Seget, Z. The urgent need for risk assessment on the antibiotic resistance spread via sewage sludge land application. Environ. Int. 2016, 87, 49-55. [CrossRef] [PubMed]

25. Paz-Ferreiro, J.; Gascó, G.; Gutiérrez, B.; Méndez, A. Soil biochemical activities and the geometric mean of enzyme activities after application of sewage sludge and sewage sludge biochar to soil. Biol. Fert Soils 2012, 48, 511-517. [CrossRef]

26. Méndez, A.; Gómez, A.; Paz-Ferreiro, J.; Gascó, G. Effects of sewage sludge biochar on plant metal availability after application to a Mediterranean soil. Chemosphere 2012, 89, 1354-1359. [CrossRef] [PubMed]

27. Méndez, A.; Cárdenas-Aguiar, E.; Paz-Ferreiro, J.; Plaza, C.; Gascó, G. The effect of sewage sludge biochar on peat-based growing media. Biol. Agric. Horticult. 2017, 33, 40-51. [CrossRef]

28. Deng, L.; Wang, K.B.; Li, J.P.; Shangguan, Z.P.; Sweeney, S. Carbon Storage Dynamics in Alfalfa (Medicago sativa) Fields in the Hilly-Gully Region of the Loess Plateau, China. Clean-Soil Air Water 2014, 42, 1253-1262. [CrossRef]

29. He, H.; Peng, Q.; Wang, X.; Fan, C.; Pang, J.; Lambers, H.; Zhang, X. Growth, morphological and physiological responses of alfalfa (Medicago sativa) to phosphorus supply in two alkaline soils. Plant Soil 2017, 416, 265-584. [CrossRef] 
30. Agnello, A.C.; Huguenot, D.; van Hullebusch, E.D.; Esposito, G. Citric acid- and Tween ${ }^{\circledR} 80$-assisted phytoremediation of a co-contaminated soil: Alfalfa (Medicago sativa L.) performance and remediation potential. Environ. Sci. Pollut. Res. 2016, 23, 9215-9226. [CrossRef] [PubMed]

31. Fan, J.-W.; Du, Y.-L.; Turner, N.C.; Wang, B.-R.; Fang, Y.; Xi, Y.; Guo, X.-R.; Li, F.-M. Changes in root morphology and physiology to limited phosphorus and moisture in a locally-selected cultivar and an introduced cultivar of Medicago sativa L. growing in alkaline soil. Plant Soil 2015, 392, 215-226. [CrossRef]

32. Bastida, F.; Torres, I.F.; Andrésabellán, M.; Baldrian, P.; Lópezmondéjar, R.; Větrovský, T.; Richnow, H.H.; Starke, R.; Ondoño, S.; García, C. Differential sensitivity of total and active soil microbial communities to drought and forest management. Glob. Chang. Biol. 2017. [CrossRef] [PubMed]

33. Xiao, X.-Y.; Wang, M.-W.; Zhu, H.-W.; Guo, Z.-H.; Han, X.-Q.; Zeng, P. Response of soil microbial activities and microbial community structure to vanadium stress. Ecotoxicol. Environ. Saf. 2017, 142, 200-206. [CrossRef] [PubMed]

34. Luo, C.; Deng, Y.; Liang, J.; Zhu, S.; Wei, Z.; Guo, X.; Luo, X. Exogenous rare earth element-yttrium deteriorated soil microbial community structure. J. Rare Earths 2018, 36, 430-439. [CrossRef]

35. Chao, Y.; Liu, W.; Chen, Y.; Chen, W.; Zhao, L.; Ding, Q.; Wang, S.; Tang, Y.-T.; Zhang, T.; Qiu, R.-L. Structure, Variation, and Co-occurrence of Soil Microbial Communities in Abandoned Sites of a Rare Earth Elements Mine. Environ. Sci. Technol. 2016, 50, 11481-11490. [CrossRef] [PubMed]

36. Zhou, L.; Li, Z.; Liu, W.; Liu, S.; Zhang, L.; Zhong, L.; Luo, X.; Liang, H. Restoration of rare earth mine areas: Organic amendments and phytoremediation. Environ. Sci. Pollut. Res. 2015, 22, 17151-17160. [CrossRef] [PubMed]

37. Liu, S.; Liu, W.; Yang, M.; Zhou, L.; Liang, H. The genetic diversity of soil bacteria affected by phytoremediation in a typical barren rare earth mined site of South China. SpringerPlus 2016, 5, 1131. [CrossRef] [PubMed]

38. Du, S.; Gao, X. Soil Analysis Technical Specifications; Chinese Industry Publisher: Beijing, China, 2006.

39. Sinclair, L.; Osman, O.A.; Bertilsson, S.; Eiler, A. Microbial Community Composition and Diversity via 16S rRNA Gene Amplicons: Evaluating the Illumina Platform. PLoS ONE 2015, 10, e0116955. [CrossRef] [PubMed]

40. Köchling, T.; Sanz, J.L.; Gavazza, S.; Florencio, L. Analysis of microbial community structure and composition in leachates from a young landfill by 454 pyrosequencing. Appl. Microbiol. Biotechnol. 2015, 99, 5657-5668. [CrossRef] [PubMed]

41. Wu, X.; Zhang, H.; Chen, J.; Shang, S.; Wei, Q.; Yan, J.; Tu, X. Comparison of the fecal microbiota of dholes high-throughput Illumina sequencing of the V3-V4 region of the 16S rRNA gene. Appl. Microbiol. Biotechnol. 2016, 100, 3577-3586. [CrossRef] [PubMed]

42. Amato, K.R.; Yeoman, C.J.; Kent, A.; Righini, N.; Carbonero, F.; Estrada, A.; Rex Gaskins, H.; Stumpf, R.M.; Yildirim, S.; Torralba, M.; et al. Habitat degradation impacts black howler monkey (Alouatta pigra) gastrointestinal microbiomes. ISME J. 2013, 7, 1344-1353. [CrossRef] [PubMed]

43. Schloss, P.D.; Westcott, S.L.; Ryabin, T.; Hall, J.R.; Hartmann, M.; Hollister, E.B.; Lesniewski, R.A.; Oakley, B.B.; Parks, D.H.; Robinson, C.J.; et al. Introducing mothur: Open-Source, Platform-Independent, Community-Supported Software for Describing and Comparing Microbial Communities. Appl. Environ. Microbiol. 2009, 75, 7537-7541. [CrossRef] [PubMed]

44. Huang, G.; Wang, L.; Zhou, Q. Combined effects of lanthanum(III) and elevated ultraviolet-B radiation on root growth and ion absorption in soybean seedlings. Environ. Sci. Pollut. Res. 2014, 21, 3621-3633. [CrossRef] [PubMed]

45. Pandey, V.; Patel, A.; Patra, D.D. Biochar ameliorates crop productivity, soil fertility, essential oil yield and aroma profiling in basil (Ocimum basilicum L.). Ecol. Eng. 2016, 90, 361-366. [CrossRef]

46. Wu, H.; Zeng, G.; Liang, J.; Chen, J.; Xu, J.; Dai, J.; Li, X.; Chen, M.; Xu, P.; Zhou, Y. Responses of bacterial community and functional marker genes of nitrogen cycling to biochar, compost and combined amendments in soil. Appl. Microbiol. Biotechnol. 2016, 100, 8583-8591. [CrossRef] [PubMed]

47. Šmilauer, P.; Lepš, J. Multivariate Analysis of Ecological Data Using CANOCO. Bull. Ecol. Soc. Am. 2004, 86, 5.

48. Blackwell, P.S.; Green, T.W.; Mason, W.K. Responses of Biopore Channels from Roots to Compression by Vertical Stresses. Soil Sci. Soc. Am. J. 1990, 54, 1088-1091. [CrossRef] 
49. Malhi, S.S.; Lemke, R.; Schoenau, J.J. Influence of time and method of alfalfa stand termination on yield, seed quality, $\mathrm{N}$ uptake, soil properties and greenhouse gas emissions under different $\mathrm{N}$ fertility regimes. Nutr. Cycl. Agroecosyst. 2010, 86, 17-38. [CrossRef]

50. Zong, Y.; Wang, Y.; Sheng, Y.; Wu, C.; Lu, S. Ameliorating soil acidity and physical properties of two contrasting texture Ultisols with wastewater sludge biochar. Environ. Sci. Pollut. Res. 2017. [CrossRef] [PubMed]

51. Herath, H.M.S.K.; Camps-Arbestain, M.; Hedley, M. Effect of biochar on soil physical properties in two contrasting soils: An Alfisol and an Andisol. Geoderma 2013, 209, 188-197. [CrossRef]

52. Busscher, W.J.; Novak, J.M.; Evans, D.E.; Watts, D.W.; Niandou, M.A.S.; Ahmedna, M. Influence of pecan biochar on physical properties of a Norfolk loamy sand. Soil Sci. 2010, 175, 10-14. [CrossRef]

53. Liu, Z.; Chen, X.; Jing, Y.; Li, Q.; Zhang, J.; Huang, Q. Effects of biochar amendment on rapeseed and sweet potato yields and water stable aggregate in upland red soil. CATENA 2014, 123, 45-51. [CrossRef]

54. Fungo, B.; Lehmann, J.; Kalbitz, K.; Thionǵo, M.; Okeyo, I.; Tenywa, M.; Neufeldt, H. Aggregate size distribution in a biochar-amended tropical Ultisol under conventional hand-hoe tillage. Soil Tillage Res. 2017, 165, 190-197. [CrossRef] [PubMed]

55. Novak, J.M.; Busscher, W.J.; Watts, D.W.; Amonette, J.E.; Ippolito, J.A.; Lima, I.M.; Gaskin, J.; Das, K.C.; Steiner, C.; Ahmedna, M.; et al. Biochars Impact on Soil-Moisture Storage in an Ultisol and Two Aridisols. Soil Sci. 2012, 177, 310-320. [CrossRef]

56. Manyà, J.J. Pyrolysis for Biochar Purposes: A Review to Establish Current Knowledge Gaps and Research Needs. Environ. Sci. Technol. 2012, 46, 7939-7954. [CrossRef] [PubMed]

57. Su, Y.Z.; Wang, X.F.; Yang, R.; Lee, J. Effects of sandy desertified land rehabilitation on soil carbon sequestration and aggregation in an arid region in China. J. Environ. Manag. 2010, 91, 2109-2116. [CrossRef] [PubMed]

58. Lu, H.; Li, Z.; Fu, S.; Méndez, A.; Gascó, G.; Paz-Ferreiro, J. Combining phytoextraction and biochar addition improves soil biochemical properties in a soil contaminated with Cd. Chemosphere 2015, 119, 209-216. [CrossRef] [PubMed]

59. Yuan, J.H.; Xu, R.K. The amelioration effects of low temperature biochar generated from nine crop residues on an acidic Ultisol. Soil Use Manag. 2011, 27, 110-115. [CrossRef]

60. Dai, Z.; Zhang, X.; Tang, C.; Muhammad, N.; Wu, J.; Brookes, P.C.; Xu, J. Potential role of biochars in decreasing soil acidification-A critical review. Sci. Total Environ. 2017, 581-582, 601-611. [CrossRef] [PubMed]

61. Yue, Y.; Cui, L.; Lin, Q.; Li, G.; Zhao, X. Efficiency of sewage sludge biochar in improving urban soil properties and promoting grass growth. Chemosphere 2017, 173, 551-556. [CrossRef] [PubMed]

62. Peng, X.; Ye, L.L.; Wang, C.H.; Zhou, H.; Sun, B. Temperature- and duration-dependent rice straw-derived biochar: Characteristics and its effects on soil properties of an Ultisol in southern China. Soil Tillage Res. 2011, 112, 159-166. [CrossRef]

63. Streubel, J.D.; Collins, H.P.; Garcia-Perez, M.; Tarara, J.; Granatstein, D.; Kruger, C.E. Influence of Contrasting Biochar Types on Five Soils at Increasing Rates of Application. Soil Sci. Soc. Am. J. 2011, 75, 1402-1413. [CrossRef]

64. Laghari, M.; Mirjat, M.S.; Hu, Z.; Fazal, S.; Xiao, B.; Hu, M.; Chen, Z.; Guo, D. Effects of biochar application rate on sandy desert soil properties and sorghum growth. CATENA 2015, 135, 313-320. [CrossRef]

65. Liu, C.; Wang, H.; Tang, X.; Guan, Z.; Reid, B.J.; Rajapaksha, A.U.; Ok, Y.S.; Sun, H. Biochar increased water holding capacity but accelerated organic carbon leaching from a sloping farmland soil in China. Environ. Sci. Pollut. Res. 2016, 23, 995-1006. [CrossRef] [PubMed]

66. Zhao, X.; Wang, J.; Wang, S.; Xing, G. Successive straw biochar application as a strategy to sequester carbon and improve fertility: A pot experiment with two rice/wheat rotations in paddy soil. Plant Soil 2014, 378, 279-294. [CrossRef]

67. Cao, X.; Ma, L.; Liang, Y.; Gao, B.; Harris, W. Simultaneous Immobilization of Lead and Atrazine in Contaminated Soils Using Dairy-Manure Biochar. Environ. Sci. Technol. 2011, 45, 4884-4889. [CrossRef] [PubMed]

68. Dong, W.-H.; Zhang, S.; Rao, X.; Liu, C.-A. Newly-reclaimed alfalfa forage land improved soil properties comparison to farmland in wheat-maize cropping systems at the margins of oases. Ecol. Eng. 2016, 94, 57-64. [CrossRef]

69. Kim, J.-S.; Sparovek, G.; Longo, R.M.; De Melo, W.J.; Crowley, D. Bacterial diversity of terra preta and pristine forest soil from the Western Amazon. Soil Biol. Biochem. 2007, 39, 684-690. [CrossRef]

70. O’Neill, B.; Grossman, J.; Tsai, M.T.; Gomes, J.E.; Lehmann, J.; Peterson, J.; Neves, E.; Thies, J.E. Bacterial Community Composition in Brazilian Anthrosols and Adjacent Soils Characterized Using Culturing and Molecular Identification. Microb. Ecol. 2009, 58, 23-35. [CrossRef] [PubMed] 
71. Faragová, N.; Gottwaldová, K.; Faragó, J. Effect of transgenic alfalfa plants with introduced gene for Alfalfa Mosaic Virus coat protein on rhizosphere microbial community composition and physiological profile. Biologia 2011, 66, 768. [CrossRef]

72. Pascault, N.; Cécillon, L.; Mathieu, O.; Hénault, C.; Sarr, A.; Lévêque, J.; Farcy, P.; Ranjard, L.; Maron, P.-A. In Situ Dynamics of Microbial Communities during Decomposition of Wheat, Rape, and Alfalfa Residues. Microb. Ecol. 2010, 60, 816-828. [CrossRef] [PubMed]

73. Sun, Z.; Bruun, E.W.; Arthur, E.; de Jonge, L.W.; Moldrup, P.; Hauggaard-Nielsen, H.; Elsgaard, L. Effect of biochar on aerobic processes, enzyme activity, and crop yields in two sandy loam soils. Biol Fert Soils 2014, 50, 1087-1097. [CrossRef]

74. Hafner, S.; Wiesenberg, G.L.B.; Stolnikova, E.; Merz, K.; Kuzyakov, Y. Spatial distribution and turnover of root-derived carbon in alfalfa rhizosphere depending on top- and subsoil properties and mycorrhization. Plant Soil 2014, 380, 101-115. [CrossRef]

75. Song, Y.; Bian, Y.; Wang, F.; Herzberger, A.; Yang, X.; Gu, C.; Jiang, X. Effects of biochar on dechlorination of hexachlorobenzene and the bacterial community in paddy soil. Chemosphere 2017, 186 (Suppl. C), 116-123. [CrossRef] [PubMed]

76. Liu, S.; Meng, J.; Jiang, L.; Yang, X.; Lan, Y.; Cheng, X.; Chen, W. Rice husk biochar impacts soil phosphorous availability, phosphatase activities and bacterial community characteristics in three different soil types. Appl. Soil Ecol. 2017, 116, 12-22. [CrossRef]

77. Hu, L.; Cao, L.; Zhang, R. Bacterial and fungal taxon changes in soil microbial community composition induced by short-term biochar amendment in red oxidized loam soil. World J. Microbiol. Biotechnol. 2014, 30, 1085-1092. [CrossRef] [PubMed]

78. Tu, C.; Ma, L.; Guo, P.; Song, F.; Teng, Y.; Zhang, H.; Luo, Y. Rhizoremediation of a dioxin-like PCB polluted soil by alfalfa: Dynamic characterization at temporal and spatial scale. Chemosphere 2017, 189 (Suppl. C), 517-524. [CrossRef] [PubMed]

79. Wang, M.C.; Chen, Y.T.; Chen, S.H.; Chang Chien, S.W.; Sunkara, S.V. Phytoremediation of pyrene contaminated soils amended with compost and planted with ryegrass and alfalfa. Chemosphere 2012, 87, 217-225. [CrossRef] [PubMed]

80. Khodadad, C.L.M.; Zimmerman, A.R.; Green, S.J.; Uthandi, S.; Foster, J.S. Taxa-specific changes in soil microbial community composition induced by pyrogenic carbon amendments. Soil Biol. Biochem. 2011, 43, 385-392. [CrossRef]

81. Yao, Q.; Liu, J.; Yu, Z.; Li, Y.; Jin, J.; Liu, X.; Wang, G. Three years of biochar amendment alters soil physiochemical properties and fungal community composition in a black soil of northeast China. Soil Biol. Biochem. 2017, 110 (Suppl. C), 56-67. [CrossRef]

82. Liu, L.; Chen, P.; Sun, M.; Shen, G.; Shang, G. Effect of biochar amendment on PAH dissipation and indigenous degradation bacteria in contaminated soil. J Soils Sediment. 2015, 15, 313-322. [CrossRef]

83. Song, Y.; Li, Y.; Zhang, W.; Wang, F.; Bian, Y.; Boughner, L.A.; Jiang, X. Novel Biochar-Plant Tandem Approach for Remediating Hexachlorobenzene Contaminated Soils: Proof-of-Concept and New Insight into the Rhizosphere. J. Agric. Food Chem. 2016, 64, 5464-5471. [CrossRef] [PubMed]

84. Haichar, F.E.Z.; Marol, C.; Berge, O.; Rangel-Castro, J.I.; Prosser, J.I.; Balesdent, J.; Heulin, T.; Achouak, W. Plant host habitat and root exudates shape soil bacterial community structure. ISME J. 2008, 2, 1221-1230. [CrossRef] [PubMed]

85. Anderson, C.R.; Condron, L.M.; Clough, T.J.; Fiers, M.; Stewart, A.; Hill, R.A.; Sherlock, R.R. Biochar induced soil microbial community change: Implications for biogeochemical cycling of carbon, nitrogen and phosphorus. Pedobiologia 2011, 54, 309-320. [CrossRef]

86. Liu, W.; Huo, R.; Xu, J.; Liang, S.; Li, J.; Zhao, T.; Wang, S. Effects of biochar on nitrogen transformation and heavy metals in sludge composting. Bioresour. Technol. 2017, 235 (Suppl. C), 43-49. [CrossRef] [PubMed]

87. Sun, D.; Meng, J.; Xu, E.G.; Chen, W. Microbial community structure and predicted bacterial metabolic functions in biochar pellets aged in soil after 34 months. Appl. Soil Ecol. 2016, 100 (Suppl. C), 135-143. [CrossRef]

88. Shrestha, B.; Anderson, T.A.; Acosta-Martinez, V.; Payton, P.; Cañas-Carrell, J.E. The influence of multiwalled carbon nanotubes on polycyclic aromatic hydrocarbon (PAH) bioavailability and toxicity to soil microbial communities in alfalfa rhizosphere. Ecotoxicol. Environ. Saf. 2015, 116 (Suppl. C), 143-149. [CrossRef] [PubMed]

89. Brussaard, L.; de Ruiter, P.C.; Brown, G.G. Soil biodiversity for agricultural sustainability. Agric. Ecosyst. Environ. 2007, 121, 233-244. [CrossRef] 
90. Moore, J.; Berlow, E.; Coleman, D.; Ruiter, P.; Dong, Q.; Hastings, A.; Johnson, N.; McCann, K.; Melville, K.; Morin, P.; et al. Detritus, trophic dynamics and biodiversity. Ecol. Lett. 2004, 7, 584-600. [CrossRef]

91. Hršelová, H.; Chvátalová, I.; Vosátka, M.; Klír, J.; Gryndler, M. Correlation of abundance of arbuscular mycorrhizal fungi, bacteria and saprophytic microfungi with soil carbon, nitrogen and phsophorus. Folia Microbiol. 1999, 44, 683-687. [CrossRef]

92. Tu, C.; Teng, Y.; Luo, Y.; Sun, X.; Deng, S.; Li, Z.; Liu, W.; Xu, Z. PCB removal, soil enzyme activities, and microbial community structures during the phytoremediation by alfalfa in field soils. J. Soils Sediment. 2011, 11, 649-656. [CrossRef]

93. Zeng, G.; Wu, H.; Liang, J.; Guo, S.; Huang, L.; Xu, P.; Liu, Y.; Yuan, Y.; He, X.; He, Y. Efficiency of biochar and compost (or composting) combined amendments for reducing $\mathrm{Cd}, \mathrm{Cu}, \mathrm{Zn}$ and $\mathrm{Pb}$ bioavailability, mobility and ecological risk in wetland soil. RSC Adv. 2015, 5, 34541-34548. [CrossRef]

94. Xu, H.-J.; Wang, X.-H.; Li, H.; Yao, H.-Y.; Su, J.-Q.; Zhu, Y.-G. Biochar Impacts Soil Microbial Community Composition and Nitrogen Cycling in an Acidic Soil Planted with Rape. Environ. Sci. Technol. 2014, 48, 9391-9399. [CrossRef] [PubMed]

95. Zhang, Y.; Tan, Q.; Hu, C.; Zheng, C.; Gui, H.; Zeng, W.; Sun, X.; Zhao, X. Differences in responses of soil microbial properties and trifoliate orange seedling to biochar derived from three feedstocks. J. Soils Sediment. 2015, 15, 541-551. [CrossRef]

96. Beesley, L.; Moreno-Jiménez, E.; Gomez-Eyles, J.L.; Harris, E.; Robinson, B.; Sizmur, T. A review of biochars' potential role in the remediation, revegetation and restoration of contaminated soils. Environ. Pollut. 2011, 159, 3269-3282. [CrossRef] [PubMed]

97. Macdonald, L.M.; Farrell, M.; Zwieten, L.V.; Krull, E.S. Plant growth responses to biochar addition: An Australian soils perspective. Biol. Fert Soils 2014, 50, 1035-1045. [CrossRef]

98. Ye, J.; Yin, H.; Peng, H.; Bai, J.; Li, Y. Pyrene removal and transformation by joint application of alfalfa and exogenous microorganisms and their influence on soil microbial community. Ecotoxicol. Environ. Saf. 2014, 110, 129-135. [CrossRef] [PubMed]

(C) 2018 by the authors. Licensee MDPI, Basel, Switzerland. This article is an open access article distributed under the terms and conditions of the Creative Commons Attribution (CC BY) license (http:/ / creativecommons.org/licenses/by/4.0/). 